\title{
EFEITOS DO CITRATO CÚPRICO EM DIFERENTES FASES DE CRIAÇÃO COMO PROMOTOR DE CRESCIMENTO DE FRANGOS DE CORTE
}

\author{
MÔNICA MARIA DE ALMEIDA BRAINER \\ Médica Veterinária
}

Orientador: Prof. Dr. JOSÉ FERNANDO MACHADO MENTEN

Dissertação apresentada à Escola Superior de Agricultura "Luiz de Queiroz", Universidade de São Paulo, para obtenção do título de Mestre em Agronomia, Área de Concentração: Ciência Animal e Pastagens.

\author{
PIR A C I C A B A \\ Estado de São Paulo - Brasil \\ Maio - 1998
}


Dados Internacionais de Catalogação na Publicação (CIP) DIVISÃo DE BIBLIOTECA E DOCUMENTAÇÃO - Campus "Luiz de Queiroz"/USP

Brainer, Mônica Maria de Almeira

Efeitos do citrato cúprico em diferentes fases de criação como promotor de crescimento de frangos de corte / Mónica Maria de Almeida Brainer. - - Piracicaba, 1998.

$81 \mathrm{p}$.

Dissertação (mestrado) - E Escola Superior de Agricultura Luiz de Queiroz, 1998. Bibliografia.

1. Cama de galinheiro 2. Cobre 3. Crescimento animal 4. Dieta animal 5. Frango de corte 6 . Resíduo animal l. Titulo 
À minha mãe Lúcia Carmen Cavalcanti de Almeida, presença constante em todas as etapas de minha vida e exemplo de força, coragem e determinação. DEDICO

À minha irmã Verônica e a todos os meus familiares pelo apoio, amor e compreensão em todos os momentos.

DEDICO

Ao Prof. Dr. Luiz Gonzaga da Paz pelo incentivo, apoio e amizade.

OFEREÇO

"Tomar nas mãos minha vida: Jogá-la a um canto talvez; Ou fazer dela uma estátua."

Anônimo. 


\section{AGRADECIMENTOS}

A Deus pela luz, força e proteção sempre presentes em todos os momentos de minha vida.

Ao Prof. Dr. José Fernando Machado Menten pela orientação, compreensão e paciência durante o curso de mestrado.

Ao Prof. Dr. Roberto Dias de Moraes e Silva pela oportunidade e orientação no início do curso.

Ao Prof. Dr. Carlos Tadeu dos Santos Dias do Departamento de Matemática e Estatística - ESALQ/USP pela colaboração nas análises estatísticas dos dados.

Ao Prof. Dr. Luís Ignácio Prochnow do Departamento de Ciência do Solo - ESALQ/USP pelas análises laboratoriais.

À Fundação Coordenação de Aperfeiçoamento de Pessoal de Nível Superior (CAPES) pela bolsa de estudo concedida.

À Fundação de Amparo à Pesquisa do Estado de São Paulo (FAPESP) pelo financiamento da pesquisa.

À SUPREMAIS Produtos Bioquímicos Ltda. pelas análises laboratoriais.

A Griftin Corporation pela doação do citrato cúprico.

A todos os professores do Departamento de Zootecnia, em especial ao Dr. Raul Dantas d'Arce e Dr. Valdomiro S. Miyada.

Aos funcionários do Departamento de Zootecnia que auxiliaram direta ou indiretamente na realização deste trabalho, em especial a Airton Bonato, Antônio Carlos Oliva e José Augusto Alves. 
A todos os colegas da Pós-Graduação, e em especial aos amigos Sônia Daróz de Morais, Michelle Costa e Marcos Martinez pela amizade, paciência e apoio em todos os momentos.

À bibliotecária Eliana M. Garcia Sabino pela revisão das referências bibliográficas e a todos os funcionários do setor de empréstimo da biblioteca pela prestatividade.

Ao meu pai, João Bezerra Brainer, pelo incentivo mesmo à distância.

A todos aqueles que colaboraram de alguma forma na realização deste trabalho. 


\section{SUMÁRIO}

Página

LISTA DE FIGURAS........................................................................

LISTA DE TABELAS .......................................................................viii

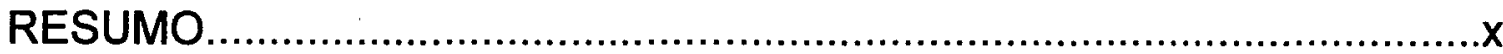

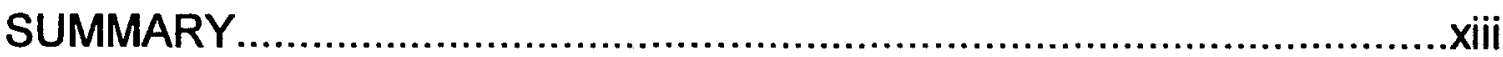

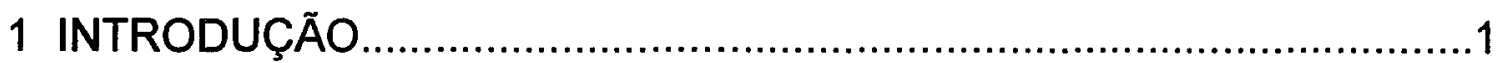

2 REVISÃO DE LITERATURA.....................................................4

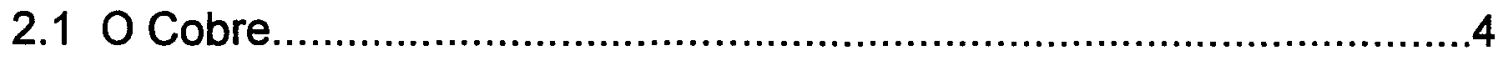

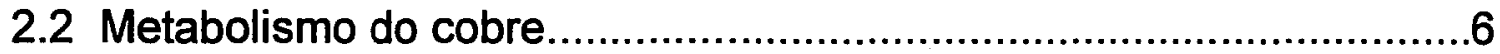

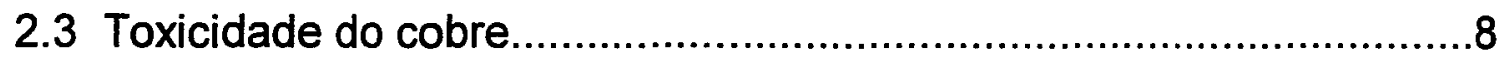

2.4 O cobre como promotor de crescimento.....................................10

2.4.1 Modo de ação....................................................................12

2.4.2 Biodisponibilidade de $\mathrm{Cu}$ das fontes mais comuns........................18

2.5 Citrato Cúprico.....................................................................20

2.6 Resíduos de cobre................................................................21

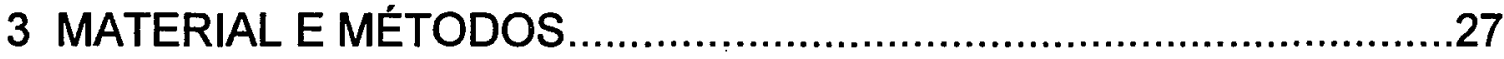

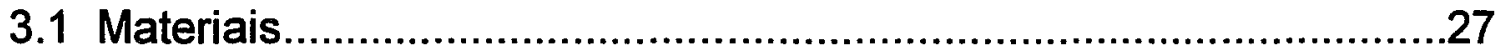

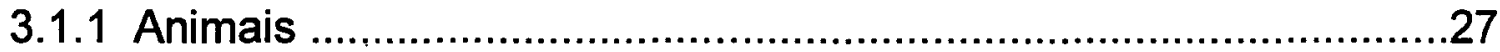

3.1.2 Rações Experimentais....................................................27

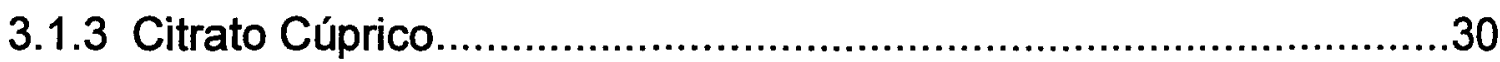

3.1.4 Instalações e Equipamentos................................................30

3.1.5 Período Experimental........................................................31

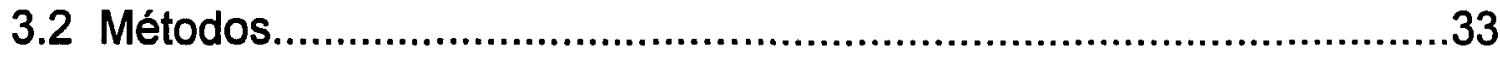


3.2.1 Preparação das instalações e equipamentos para o recebimento dos pintos.

3.2.2 Condução do Experimento...................................................34

3.2.3 Delineamento Experimental.................................................36

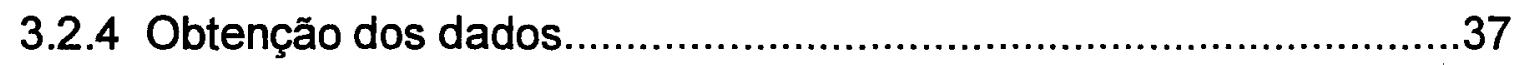

3.2.5 Coleta e análise das amostras de cama...................................38

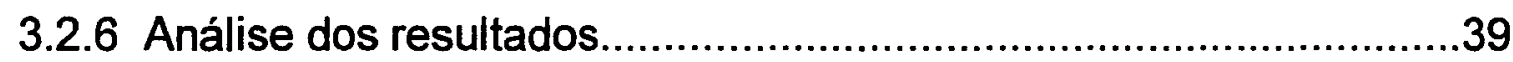

4 RESULTADOS E DISCUSSĀO..................................................41

4.1 Peso vivo médio (PVM), Ganho médio em peso (GMP), Consumo alimentar médio (CONS) e Conversão alimentar (CA)..................41

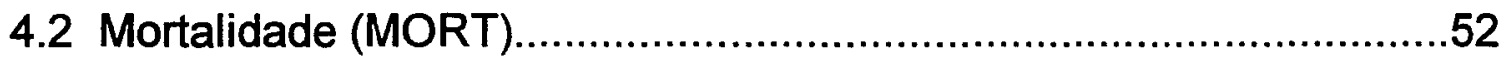

4.3 Resíduos de Cu na cama (RES)............................................53

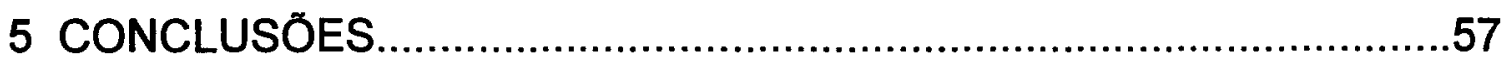

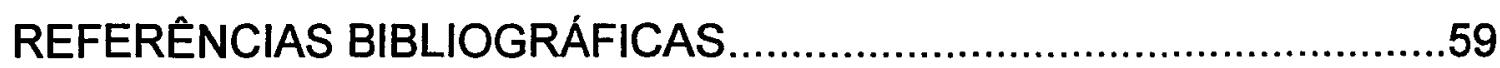

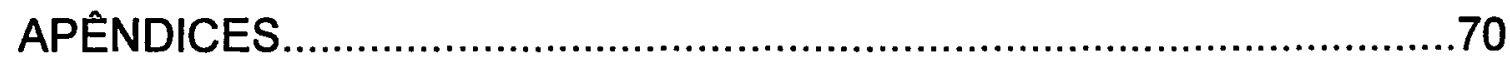




\section{LISTA DE FIGURAS}

Página

1 Vista externa do aviário experimental................................ 32

2 Vista interna do aviário experimental e suas divisões (boxes) 


\section{LISTA DE TABELAS}

Página

1 Resultados de análise do milho e do farelo de soja utilizados na ração basal....................................................................... 28

2 Composição percentual e valores calculados das dietas basais

3 Efeito dos tratamentos no PVM das aves testados aos 21 e aos 42 dias de idade.

4 Efeito dos tratamentos no GMP das aves testados nos períodos de 1 a 21 dias, de 22 a 42 dias e de 1 a 42 dias da criação

5 Efeito dos tratamentos no CONS das aves testados nos periodos de 1 a 21 dias, de 22 a 42 dias e de 1 a 42 dias da criação.

6 Efeito dos tratamentos na $\mathrm{CA}$ das aves testados nos períodos de 1 a 21 dias, de 22 a 42 dias e de 1 a 42 dias da criação. 
7 Efeito dos tratamentos na MORT das aves testados nos períodos de 1 a 21 dias, de 22 a 42 dias e de 1 a 42 dias da criação.

8 Efeito dos tratamentos nos resíduos de Cu na cama das aves aos 42 dias da criação 


\title{
EFEITOS DO CITRATO CÚPRICO EM DIFERENTES FASES DE CRIAÇÃO COMO PROMOTOR DE CRESCIMENTO DE FRANGOS DE CORTE
}

\author{
Autora: MÓNICA MARIA DE ALMEIDA BRAINER \\ Orientador: Prof. Dr. JOSÉ FERNANDO MACHADO MENTEN
}

\section{RESUMO}

Este trabalho foi conduzido no Departamento de Zootecnia da ESALQ/USP, em Piracicaba/SP e teve como principal objetivo estudar os efeitos do citrato cúprico sobre o desempenho de frangos de corte em diferentes fases da criação em comparação ao sulfato cúprico, avaliando as variações das respostas nas fases, como também, analisar resíduos de cobre $(\mathrm{Cu})$ na cama.

Foram utilizados 1.200 pintos de corte machos da linhagem Ross, com um dia de idade, num período total de 42 dias. A ração basal utilizada durante o período experimental foi dividida em três tipos de acordo com as exigências nutricionais das fases de criação: inicial (1 a 21 dias), crescimento (22 a 35 dias) e final (36 a 42 dias), sendo formulada à base de milho e farelo de soja.

O delineamento experimental utilizado foi em blocos ao acaso, com cinco tratamentos, seis repetições e 40 aves por parcela. Foram testadas as suplementações de citrato cúprico (75 mg Cu/kg) na 
dieta em diferentes fases de criação. Assim, os tratamentos corresponderam a uma dieta basal (DB) como controle de 1 a 42 dias, DB + citrato cúprico de 1 a 21 dias, DB + citrato cúprico de 22 a 42 dias, DB + citrato cúprico de 1 a 42 dias e DB + sulfato cúprico pentahidratado (200 $\mathrm{mg} \mathrm{Cu} / \mathrm{kg}$ ) de 1 a 42 dias. As variáveis analisadas foram peso vivo médio (PVM), ganho médio em peso (GMP), consumo alimentar (CONS), conversão alimentar (CA), mortalidade (MORT) e resíduo de Cu na cama (RES).

Não houve efeito significativo $(P>0,05)$ da suplementação do citrato cúprico nas diferentes fases testadas e do sulfato cúprico em comparação à dieta controle para PVM e GMP. A suplementação de citrato cúprico nas diferentes fases testadas resultou em um CONS maior no periodo total do que o obtido com o sulfato cúprico $(P=0,08)$. Quando analisado no período de 22 a 42 dias, o tratamento DB + citrato cúprico de 22 a 42 dias apresentou uma pior $C A$, sendo significativamente diferente $(P<0,05)$ apenas da CA do tratamento sulfato. As aves controle tiveram uma maior mortalidade no periodo total do que as aves suplementadas com citrato $(P=0,07)$. Houve diferença estatística $(P<0,01)$ entre os resíduos de Cu na cama com valores de 43 e 54 ppm de Cu com DB e citrato 1-21 dias, respectivamente; 97 e 115 ppm de Cu com citrato 22-42 dias e citrato 1-42 dias, respectivamente; e 197 ppm de $\mathrm{Cu}$ com sulfato.

Como o Cu não foi eficiente como promotor de crescimento de frangos de corte e não houve ação do citrato cúprico nas diferentes fases testadas, pode-se sugerir estudos mais detalhados sobre os efeitos do citrato comparado ao sulfato cúprico, repetindo-se sucessivamente os 
ensaios nas mesmas instalações, a fim de criar condições propícias para a ação do Cu como agente antimicrobiano. 


\title{
EFFECTS OF CUPRIC CITRATE ON DIFFERENT PHASES AS GROWTH PROMOTANT OF BROILERS
}

\author{
Author: MÔNICA MARIA OF ALMEIDA BRAINER \\ Adviser: Prof. Dr. JOSÉ FERNANDO MACHADO MENTEN
}

\section{SUMMARY}

This study was conducted at ESALQ/USP, Piracicaba/SP to study the effects of supplementation of cupric citrate in the diet on growth performance of broilers in different phases in comparison to cupric sulfate, evaluating the variations in the phases, as well as, to analyze residues of $\mathrm{Cu}$ in the litter.

One thousand and two hundred day-old male broiler chicks (Ross) were used in a total period of 42 days. The basal diet used during the experimental period was divided in three types according to the nutritional demands: starter (1 to 21 days), grower (22 to 35 days) and finisher ( 36 to 42 days), based on corn and soybean meal.

A randomized block design was used, with five treatments, six replicates and 40 birds per pen. The treatments corresponded to a basal diet (DB) as control, $\mathrm{DB}+$ cupric citrate $(75 \mathrm{ppm} \mathrm{Cu})$ from 1 to 21 days, DB + cupric citrate from 22 to 42 days, DB + cupric citrate from 1 to 42 days and DB + cupric sulfate pentahydrate (200 ppm Cu) from 1 to 42 days. The analyzed variables were body weight (PVM), weight gain 
(GMP), feed intake (CONS), feed conversion ratio (CA), mortality (MORT) and residue of $\mathrm{Cu}$ in the litter (RES).

There were no significant effect $(P>0,05)$ of cupric citrate in the different phases and of cupric sulfate supplemented in the diet in comparison to the control diet for PVM and GMP. Cupric citrate fed broilers had higher feed intake in the 1-42 d period than the ones receiving cupric sulfate $(P=0,08)$. Cupric citrate supplementation on the $22-42 d$ period resulted in worse CA compared to the broilers receiving cupric sulfate $(P<0,05)$. Citrate supplemented birds had lower mortality than the controls $(P=0,07)$. There were differences $(P<0,01)$ in the $\mathrm{Cu}$ residues in the litter with values of 43 and $54 \mathrm{ppm}$ of $\mathrm{Cu}$ with DB and citrate 1-21 days, 97 and $115 \mathrm{ppm}$ of $\mathrm{Cu}$ with citrate 22-42 days and citrate $1-42$ days and $197 \mathrm{ppm}$ of Cu with sulfate.

As the Cu was not efficient as growth promotant of broilers, differences were not observed among the two sources (cupric citrate and cupric sulfate) and there were no differences due to supplemention of the citrate in different phases, it can be suggested that more detailed studies on the effects of the citrate compared to the cupric sulfate with various sucessive trials successively in the same pens to create favorable conditions for the action of the $\mathrm{Cu}$ as antimicrobial agent. 


\section{INTRODUÇÃO}

$\mathrm{Na}$ Indústria Avícola moderna, a nutrição representa a maior parcela dos custos de produção. Desde os anos 50, uma grande variedade de substâncias antibacterianas têm sido utilizadas como promotores de crescimento com o objetivo de melhorar o desempenho das aves. A utilização de promotores de crescimento foi uma alternativa que muito contribuiu para a redução dos custos.

O cobre $(\mathrm{Cu})$ é um micromineral essencial que muitas vezes é utilizado na ração em doses que excedem a exigência das aves. Altos níveis de $\mathrm{Cu}$ são adicionados na dieta devido a sua ação sobre o aumento da taxa de crescimento e eficiência alimentar, agindo então como um promotor de crescimento.

O mecanismo pelo qual altos níveis de $\mathrm{Cu}$ dietético melhoram a performance de aves e suínos ainda não é totalmente conhecido. Diversos autores sugerem que o Cu possui o mesmo modo de ação dos agentes antimicrobianos, agindo sobre a flora microbiana intestinal, porém estudos recentes indicam a possibilidade deste mineral possuir ação sistêmica.

O Cu pode ser adicionado à ração sob a forma de sulfato cúprico pentahidratado $\left(\mathrm{CuSO}_{4} .5 \mathrm{H}_{2} \mathrm{O}\right)$, óxido cúprico (CuO) e carbonato cúprico $\left(\mathrm{CuCO}_{3} \mathrm{Cu}(\mathrm{OH})_{2}\right)$ como estimulante do crescimento (Rostagno et 
al., 1994). Como promotor de crescimento a forma sulfato é a mais utilizada na indústria avícola.

Em estudos conduzidos por Pesti \& Bakalli (1996) foram obtidos resultados de melhora no desempenho com a utilização de duas fontes de $\mathrm{Cu}$ (citrato cúprico e sulfato cúprico pentahidratado), que confirmaram sua ação como promotor de crescimento para frangos de corte. Porém, o citrato cúprico apresentou uma melhor resposta no desempenho dos animais a níveis de suplementação mais baixos do que o sulfato pentahidratado. Em adição a esses resultados, foi observado que houve uma redução dos resíduos de $\mathrm{Cu}$ na cama das aves suplementadas com citrato cúprico em comparação com o sulfato cúprico. Um fato interessante verificado nesses estudos foi que a suplementação de Cu nas fases finais da criação teve um efeito promotor de crescimento mais pronunciado do que no período inicial. Quando usado como promotor de crescimento em suínos, o efeito do $\mathrm{Cu}$ é mais marcante na fase inicial do que nas posteriores (Cromwell, 1991).

Apesar da comprovada eficácia do Cu sobre o crescimento de aves e suínos a níveis farmacológicos, é necessário diminuir o seu uso na alimentação de frangos de corte devido ao acúmulo de resíduos na cama que posteriormente servirá como fertilizante. Com $100 \mathrm{mg} \mathrm{Cu} / \mathrm{kg}$ na ração, o esterco seco contém aproximadamente $600 \mathrm{mg} \mathrm{Cu/kg}$. Ultrapassando-se a margem crítica de $\mathrm{Cu}$ disponivel para plantas, provoca-se uma redução na produtividade, além de aumentar o conteúdo de metal na pastagem a níveis que são tóxicos para ovinos (Andriguetto et al., 1990; Maynard, 1984).

O valor da cama de frango como fonte de nutrientes para alimentação animal e adubação tem sido reconhecido há muitos anos. $O$ 
esterco de frangos de corte contém mais elementos nutritivos do que qualquer outro esterco na produção animal. Os mais importantes constituintes dos fertilizantes - Nitrogênio (N), Fósforo $\left(\mathrm{P}_{2} \mathrm{O}_{5}\right)$ e Potássio $\left(\mathrm{K}_{2} \mathrm{O}\right)$ são os de maior valor no esterco de aves (Vest \& Dyer, 1993), porém, atualmente há uma grande preocupação quanto ao uso de altos niveis de Cu na ração animal, devido a seus resíduos na cama; pois, sendo o $\mathrm{Cu}$ praticamente insolúvel no solo, constitui-se um importante elemento na poluição ambiental.

Sendo o citrato cúprico uma forma orgânica do $\mathrm{Cu}$, agindo como promotor de crescimento a níveis mais baixos que os normalmente usados com o sulfato cúprico, e conseqüentemente reduzindo resíduos de Cu na cama, faz-se então necessário maiores conhecimentos sobre os efeitos do uso de citrato cúprico na dieta em diferentes fases da criação de frangos de corte.

O presente estudo teve como objetivos:

- Avaliar os efeitos do citrato cúprico no desempenho de frangos de corte quando suplementado em diferentes fases da criação (1-21 dias, 22-42 dias ou 1-42 dias), e comparar com os efeitos do sulfato cúprico;

- Observar variações na resposta do citrato cúprico nas diferentes fases testadas;

- Determinar as concentrações de Cu na cama de frangos submetidos à dieta suplementada com citrato cúprico nas diferentes fases e sulfato cúprico. 


\section{REVISÃO DE LITERATURA}

\subsection{O Cobre}

O cobre $(\mathrm{Cu})$ é um constituinte normal e constante do organismo animal e sua concentração varia conforme a espécie e idade do animal. Os animais jovens possuem concentrações maiores que os animais adultos (Andriguetto et al., 1990).

São várias as funções metabólicas do $\mathrm{Cu}$. Possui papel essencial na respiração celular e metabolismo do ferro, no desenvolvimento do tecido conjuntivo, na formação dos ossos e na queratinização e pigmentação dos tecidos. É também parte integrante de diversas metaloenzimas, tais como citocromo C oxidase, tirosinase, uricase, lisil oxidase, superóxido dismutase, diamina oxidase, monoamino-oxidase plasmática e benzilamina-oxidase (Maynard, 1984; McDowell,1992; Swenson \& Reece, 1996).

A citocromo $\mathrm{C}$ oxidase é responsável pela maior parte (provavelmente mais de $90 \%$ ) do oxigênio consumido pelos seres vivos e a superóxido dismutase é uma enzima do citossol que desdobra cataliticamente o radical livre tóxico, ín superóxido $\left(\mathrm{O}_{2}{ }^{-}\right)$, gerado durante o metabolismo aeróbico. Proteínas idênticas à superóxido dismutase foram isoladas de diversas fontes e na ausência de funções enzimáticas 
conhecidas receberam uma diversidade de nomes, inclusive eritrocupreína (extraída de hemácias), hepatocupreína (do fígado) e cerebrocupreína (do cérebro) (Harper et al., 1982).

O Cu absorvido é depositado em grande parte no fígado, e muitos fatores parecem influenciar sua concentração neste órgão, como espécie, idade do animal, composição química da dieta e várias condições de enfermidade. A concentração de $\mathrm{Cu}$ no fígado tem sido usada como um indicador da condição do animal, indicando deficiência quando muito baixa e toxicidade quando muito alta (Kolb, 1972; Mertz, 1987). No sangue, o $\mathrm{Cu}$ aparece primeiro no plasma como íons cúpricos livres na albumina. Durante a síntese hepática da ceruloplasmina, o Cu é firmemente ligado a esta metaloproteína, o qual é então liberado para a circulação geral. A ceruloplasmina é uma $\alpha_{2}$-globulina com um peso molecular de 160.000 e sete átomos de Cu por molécula, que favorece a oxidação do ferro (Fe) da forma ferrosa em férrica, o que é necessário para a ligação do Fe à transferrina (Underwood, 1977; NRC, 1980; Swenson e Reece, 1996).

Mais de $50 \%$ do $\mathrm{Cu}$ no sangue está nos eritrócitos, e destes, pelo menos $80 \%$ está presente como uma superóxido-dismutase (eritrocupreina). O Cu do plasma ocorre de duas formas principais, uma firmemente e outra frouxamente ligada. $\mathrm{O} \mathrm{Cu}$ firmemente ligado, compreendendo $80-95 \%$ do $\mathrm{Cu}$ plasmático total, consiste de ceruloplasmina. O Cu frouxamente ligado é conhecido como de "leitura direta" porque ele reage livremente com os reagentes que o complexam, estando frouxamente ligado a uma proteína, provavelmente a albumina sérica. Em galinhas e perus, uma menor quantidade de Cu está presente 
no plasma como ceruloplasmina em comparação aos mamíferos (Underwood, 1977, NRC, 1980; Harper et al., 1982).

Os distúrbios clínicos associados à deficiência de $\mathrm{Cu}$ incluem anemia, problemas ósseos, ataxia neonatal, despigmentação e crescimento anormal de pêlos e lã, baixo desenvolvimento, queda de desempenho reprodutivo, insuficiência cardiaca e distúrbios gastrintestinais (Swenson e Reece, 1996). Em aves, pode produzir uma anemia microcítica hipocrômica e despigmentação das penas. Como ० $\mathrm{Cu}$ é essencial na síntese de elastina, uma deficiência pode resultar em vasos sangüíneos finos e fracos, tendo sido sugerido como uma causa do aneurisma dissecante em aves, especialmente, perus (The Merck Veterinary Manual, 1991).

\subsection{Metabolismo do cobre}

Estudos sobre o mecanismo de absorção de $\mathrm{Cu}$ em aves desenvolvidos por Starcher (1969) demonstraram que o mesmo é absorvido no proventrículo e duodeno, sendo que a absorção no duodeno é cinco vezes maior que no proventrículo. Isto se deve a uma maior concentração de metaloproteínas ligadoras de $\mathrm{Cu}$ no duodeno que desempenham importante função no processo de absorção. A ligação do Cu a uma ou mais proteínas no duodeno com peso molecular de 10.000 , é uma importante etapa no processo de absorção, e o cádmio (Cd) e o zinco $(\mathrm{Zn})$ inibem a sua absorção por competição pelo mesmo sítio de ligação das proteínas ligadoras de Cu no duodeno. 
A absorção do $\mathrm{Cu}$ é influenciada pela quantidade e forma química na qual é administrado, pelo nível dietético de outros minerais e substâncias orgânicas, pela acidez do conteúdo intestinal na área de absorção e pela idade do animal (Underwood, 1977; Andriguetto et al., 1990). O carbonato cúprico $\left(\mathrm{CuCO}_{3}\right)$ e as formas hidrossolúveis, sulfato cúprico $\left(\mathrm{CuSO}_{4} \cdot \mathrm{H}_{2} \mathrm{O}\right)$, nitrato cúprico $\left[\mathrm{Cu}\left(\mathrm{NO}_{3}\right)_{2}\right]$ e cloreto cúprico $\left(\mathrm{CuCl}_{2}\right)$ são melhor absorvidos do que o óxido cúprico (CuO) (NRC, 1980). Há uma boa evidência de que a absorção intestinal do Cu é regulada pela necessidade do organismo, e que a metalotioneína nas células epiteliais do intestino devem desempenhar importante papel nesta regulação e na interação entre o $\mathrm{Cu}$ e $\circ \mathrm{Zn}$ (McDowell, 1992). Em geral, é pobremente absorvido, com apenas $5 \%$ a $10 \%$ do $\mathrm{Cu}$ ingerido sendo absorvido e retido (Swenson \& Reece, 1996).

O $\mathrm{Cu}$ parece ser absorvido por dois mecanismos, um saturado e outro não saturado. Em baixas concentrações, é absorvido por transporte ativo, enquanto em concentrações elevadas atravessa a mucosa por difusão simples. Este mineral apresenta a característica de passar prontamente do estado cúprico $\left(\mathrm{Cu}^{++}\right)$para cuproso $\left(\mathrm{Cu}^{+}\right)$e viceversa. Para ser absorvido, o mineral deve se encontrar no estado cúprico. Este fato é nutricionalmente importante, uma vez que o $\mathrm{Cu}$ encontra-se freqüentemente envolvido em reações de troca de elétrons. Portanto, a presença de substâncias redutoras na dieta pode manter o $\mathrm{Cu}$ em estado cuproso e interferir em sua absorção (McDowell, 1992; Rutz, 1994). A ingestão elevada de carbonato de $\mathrm{Ca}$, sulfato ferroso, fitatos, ácido ascórbico, $\mathrm{Fe}, \mathrm{Zn}, \mathrm{Mo}, \mathrm{Mn}$ e $\mathrm{Cd}$ afetam a absorção, retenção e distribuição de $\mathrm{Cu}$ no organismo. O sulfato, em combinação com o Cu, 
forma um composto insolúvel e não absorvivel que é o sulfato cúprico (Andriguetto et al. 1990; McDowell, 1992).

A excreção do $\mathrm{Cu}$ se dá principalmente pelas fezes. A maioria do $\mathrm{Cu}$ fecal provém daquele ingerido e não absorvido e secundariamente do proveniente da bile e da mucosa intestinal. Quantidades intermediárias são excretadas através da urina, leite e pequenas quantidades através da transpiração (Andriguetto et al. 1990; McDowell, 1992).

\subsection{Toxicidade do cobre}

O consumo excessivo e prolongado de $\mathrm{Cu}$ provoca um elevado acúmulo nos tecidos, especialmente no fígado, com diminuição na concentração de hemoglobina sangüínea e no hematócrito. A função hepática é prejudicada no envenenamento pelo $\mathrm{Cu}$ (Andriguetto et al. 1990; Swenson \& Reece, 1996).

Norvell et al. (1974) realizaram um estudo a fim de determinar os efeitos de altos niveis de sulfato cúprico (720 e 480 ppm de $\mathrm{Cu})$ na dieta de frangos de corte durante oito semanas. A mortalidade, peso relativo do fígado e observações histolológicas no papo, duodeno, íleo, pâncreas e fígado não foram afetados significativamente pela suplementação de $\mathrm{Cu}$. Os resultados deste estudo indicaram que 720 ppm de Cu na dieta afetou o crescimento e 480 e 720 ppm elevaram os níveis de Cu no tecido do fígado das aves. 
Diversos autores têm verificado uma ação de altos níveis de Cu na dieta de frangos de corte sobre o tecido de revestimento da moela. Fisher et al. (1973) observaram que o revestimento da moela de aves suplementadas com 600 ppm de $\mathrm{Cu}$ (sulfato cúprico) apresentaram extensas lesões, atribuídas ao aumento do desprendimento das células glandulares dentro da camada de koilina e à interrupção na produção de koilina na moela. Houve mudanças similares, porém menos severas, na moela de aves suplementadas com 400 ppm de $\mathrm{Cu}$ e, um leve aumento na descamação na moela de algumas aves que receberam 200 ppm de Cu. Poupolis \& Jensen (1976) observaram leves melhoras no ganho de peso e/ou eficiência alimentar quando as dietas foram suplementadas com Cu (250 ppm de Cu como sulfato cúprico pentahidratado), porém 500 a $1000 \mathrm{ppm}$ reduziram o crescimento e a eficiência. Foram observadas erosões de moela com 250 ppm tendo sua severidade aumentado com níveis maiores. Jensen et al. (1991) também verificaram que a severidade da erosão aumenta com a concentração de $\mathrm{Cu}$, e concluíram que a suplementação de sulfato cúprico na dieta pode ser considerada como a possível causa de lesões orais observadas no exame "post-morten" de aves. Em adição a esses resultados, Anjum et al. (1992) observaram que aves recebendo 500 e 1000 ppm de sulfato cúprico na dieta apresentaram uma redução no consumo alimentar e um aumento no consumo de água, além de um leve aumento no peso do pâncreas, lesões degenerativas moderadas no fígado, erosões de vários graus na moela e uma tendência de aumento no número de eritrócitos.

Em experimento conduzido por Widerman et al. (1996), alimentos formulados para conter 0, 250, 500 e 750 ppm de $\mathrm{Cu}$ foram fornecidos a frangos de corte por quatro semanas. Níveis iguais ou acima 
de $250 \mathrm{ppm}$ aumentaram significativamente a incidência de proventriculite. Esses resultados mostram que o $\mathrm{Cu}$ na dieta acima de 200 ppm pode provocar sintomas clássicos de aumento no proventrículo e proventriculite em frangos de corte.

O NRC (1980) indica que 300 ppm de Cu é o nível máximo tolerável para frangos, porém foi bem observado em diversos experimentos que, concentrações de $\mathrm{Cu}$ na dieta que excedem 250 ppm provocam redução no consumo e crescimento das aves. Esta redução no desempenho tem sido parcialmente atribuída a uma deficiência de aminoácidos sulfurados, pois aves alimentadas com altos níveis de Cu na dieta (> 250 ppm) têm um aumento na exigência de tais aminoácidos (Robbins \& Baker, 1980).

\subsection{O cobre como promotor de crescimento}

O sulfato cúprico tem sido usado por muitos anos na avicultura como tratamento na erosão da moela, enterite e vários tipos de micoses. Em 1955, foi observado que 250 ppm de Cu suplementar, como sulfato cúprico, aumentou a taxa de crescimento de leitões, semelhante à ação dos antibióticos (Scott, 1969). As necessidades de Cu para frangos de corte determinada pelo NRC (1994) são de 8 ppm, porém Scott et al. (1969) conduziram estudos com perus comparando os efeitos promotores do crescimento de 50 e 100 ppm de Cu como sulfato cúprico, com aqueles de uma variedade de antibióticos e outros agentes antimicrobianos. Os resultados mostraram que o sulfato cúprico na dieta 
(100 ppm de $\mathrm{Cu}$ ) produziu um crescimento aproximadamente $10 \%$ maior do que com a dieta basal, o que foi equivalente ao obtido com os antibióticos.

Em uma série de ensaios, Fisher et al. (1973) observaram que a adição de 160 ou 175 ppm de sulfato cúprico na dieta de frangos de corte machos e fêmeas, provocou uma resposta significativa no peso corporal e na conversão alimentar. Guenthner et al. (1978) verificaram que níveis de 120 a 240 ppm de $\mathrm{Cu}$ (óxido ou sulfato) estimularam a taxa de crescimento de perus acima de $10 \%$ com redução na exigência alimentar.

Hoda \& Maha (1995) ao estudarem a eficiência do $\mathrm{Cu}$ como promotor de crescimento em frangos de corte nas formas de carbonato cúprico, sulfato cúprico e óxido cúprico (75 e 150 ppm) observaram que ambos os níveis de $\mathrm{CuCO}_{3}$ e $150 \mathrm{ppm}$ de $\mathrm{CuSO}_{4}$ aumentaram significativamente o ganho de peso melhorando a eficiência alimentar, enquanto que o $\mathrm{CuO}$ não apresentou nenhum efeito como promotor de crescimento.

A suplementação de $250 \mathrm{ppm}$ 'e sulfato cúprico na dieta aumentou o ganho de peso $(4,95 \%)$ e melhorou a conversão alimentar $(3,28 \%)$ em frangos de corte, porém quando o Cu foi utilizado acima deste nível o benefício foi menor (Pesti \& Bakalli, 1996). Do mesmo modo, Ewing et al. (1997) adicionaram $125 \mathrm{ppm} \mathrm{Cu}$ nas formas de sulfato cúprico pentahidratado, citrato cúprico e oxicloreto cúprico na dieta de frangos de corte e obtiveram resultados significativos no crescimento das aves quando comparado à dieta controle.

Hawbaker et al. (1959) relataram que o radical $\mathrm{Cu}$, e não o radical $\mathrm{SO}_{4}$, foi responsável pela melhora no desempenho de suínos após 
testar o $\mathrm{CuSO}_{4} .5 \mathrm{H}_{2} \mathrm{O}, \mathrm{Na}_{2} \mathrm{SO}_{4}$ e CuCl. Pesti \& Bakalli (1996) comparando as respostas do citrato e sulfato cúprico no desempenho de frangos de corte, observaram que houve melhora significativa com a utilização de ambas as fontes e concluíram que o efeito promotor de crescimento do sulfato cúprico deve-se ao Cu e não ao sulfato.

\subsubsection{Modo de ação}

Os mecanismos pelos quais o $\mathrm{Cu}$ promove a melhora do desempenho das aves e suínos ainda não foram totalmente esclarecidos. Em alguns casos, a resposta de crescimento é similar à obtida com antibióticos, porém em outros não se verifica tal fato. Pesquisas realizadas nos EUA demonstraram que quase $75 \%$ dos ensaios em que 0 Cu é combinado com um antibiótico, resultam em um efeito aditivo sobre o crescimento e eficiência alimentar dos animais suplementados (Cunha, 1977).

Diversos autores sugerem que este mineral possui, possivelmente, o mesmo modo de ação dos agentes antimicrobianos. Segundo Visek (1978), os quatro principais mecanismos são: redução da destruição microbiana de nutrientes essenciais ou um aumento na síntese de vitaminas ou outros fatores de crescimento, redução da produção microbiana de toxinas depressoras do crescimento, aumento da eficiência de utilização e absorção de nutrientes e eliminação dos microrganismos responsáveis por infecções subclínicas. 
De acordo com resultados de ensaios realizados para esclarecer quais os mecanismos que explicam o modo de ação do Cu na promoção de crescimento, podem ser propostos os seguintes:

a) Efeito nutricional: economia de nutrientes e neutralização das substâncias tóxicas produzidas pelos microrganismos:

Hawbaker et al. (1959) e Bunch et al. (1961) observaram mudanças nos padrões da flora fecal como resultado de altos níveis de $\mathrm{Cu}$, e sugeriram que a variação na resposta de crescimento dos suínos pode ser associada com a variação na flora intestinal.

Jensen \& Maurice (1978) adicionando 120 a 250 ppm de $\mathrm{Cu}$ em rações práticas para frangos de corte, verificaram mudanças na aparência do ceco e na excreta das aves. As concentrações de $\mathrm{Cu}$ no conteúdo cecal alcançaram níveis acima de 5.000 ppm, sugerindo que o mecanismo de ação do Cu na mudança da aparência do ceco, pode estar associada à inibição da fermentação normal que ocorre nesta parte do trato gastrointestinal. Enquanto que Hoda \& Maha (1995) observaram que o peso do ceco foi aumentado significativamente em todas as aves suplementadas com 75 e 150 ppm de carbonato cúprico, óxido cúprico ou sulfato cúprico por seis semanas. Os conteúdos cecais foram afetados pelo sulfato cúprico, levemente afetado pelo carbonato cúprico, mas o óxido cúprico não teve efeito. A morfologia histológica intestinal indicou que o Cu tem ação antimicrobiana dentro do intestino.

Radecki et al. (1992) concluíram que 250 ppm de Cu na dieta de suínos pode reduzir a taxa de reposição das células epiteliais intestinais, especialmente no jejuno, o qual pode resultar em uma diminuição da exigência de energia para a manutenção desse tecido, e 
conseqüentemente, aumentar a quantidade de energia disponível para o ganho de peso.

Vários experimentos confirmam que os agentes antibacterianos agem sobre as bactérias aderidas à mucosa intestinal reduzindo o número de células inflamatórias na parede do intestino e diminuindo o grau de descamação e renovação das vilosidades. Com isto há uma redução do "turnover" das células epiteliais aumentando a capacidade absortiva do trato gastrointestinal. Além do que, a atividade das bactérias intestinais produz uma gama complexa de substâncias, muitas das quais são altamente tóxicas ao animal, que necessita de energia para se desintoxicar. Com a modificação da atividade das bactérias intestinais para que não produzam substâncias tóxicas, sobrará energia, e esta estará disponivel para melhorar o rendimento (Dierick et al., 1986).

Isto pode ser comprovado por Menten (1995) que estudando a eficácia, o efeito sinérgico e o modo de ação de agentes antimicrobianos como promotores do crescimento de suínos, concluiu que os efeitos independentes de alto nível de $\mathrm{Cu}$, causando redução na taxa de proliferação celular no epitélio intestinal e de tiamulin-sulfametazinafurazolidona, causando redução no peso gastrointestinal, resultam em uma menor necessidade de energia e/ou proteína para as visceras, aumentando sua disponibilidade para o crescimento.

\section{b) Efeito metabólico:}

Zhou et al. (1994a) injetaram um complexo Cu-histidinato através da veia jugular de leitões por 18 dias e obtiveram, em dois experimentos, aumentos no ganho de peso de 15 a $30 \%$ e na eficiência 
alimentar de 12 a $24 \%$. O efeito no desempenho foi acompanhado por ligeiros aumentos na atividade mitogênica do soro e do nível de RNAm para hormônio de crescimento na pituitária. Os autores descartaram a possibilidade de o $\mathrm{Cu}$ ter agido após sua liberação no trato intestinal, concluindo que o mesmo realmente apresentou uma ação sistêmica como promotor de crescimento.

Dois experimentos foram conduzidos por Zhou et al. (1994b) para estudar a função do consumo e da eficiência alimentar no crescimento estimulado pelo $\mathrm{Cu}$ de leitões desmamados. Os autores concluíram que a melhora no desempenho devido ao $\mathrm{Cu}$ foi muito maior nos porcos alimentados "ad libitum" do que nos porcos com restrição alimentar, o que sugere que o maior efeito do $\mathrm{Cu}$ é o estímulo ao consumo alimentar. Uma provável hipótese para explicar esse fato é que o Cu estimula a síntese do hormônio de crescimento $(G H)$ e esse potencial de crescimento, provavelmente, exige nutrientes adicionais provenientes de um aumento do consumo alimentar.

Aoyagi \& Baker (1995) conduziram um ensaio de digestibilidade em galos adultos alimentados com milho moído para confirmar a teoria de que aves alimentadas com altas doses de $\mathrm{Cu}$ (250 ppm) podem exibir uma maior digestibilidade da hemicelulose. Os resultados confirmaram a teoria e demonstraram evidências de que enzimas lisossomais na bile podem ter sido aumentadas como um resultado da suplementação de $\mathrm{Cu}$. Algumas dessas enzimas, especialmente a $\beta$-glucuronidase, podem aumentar a digestibilidade da hemicelulose presente em dietas práticas. Isto pode explicar, em parte, o efeito promotor de crescimento do $\mathrm{Cu}$. 
Dove (1995) avaliou o efeito da adição de 15 ou 250 ppm de $\mathrm{Cu}\left(\mathrm{CuSO}_{4} .5 \mathrm{H}_{2} \mathrm{O}\right)$ e 0 ou $5 \%$ de gordura animal na dieta de suínos sobre a utilização de nutrientes. Os resultados indicaram que a digestibilidade dos nutrientes é influenciada pelo $\mathrm{Cu}$ e pelo nível de gordura da dieta, e que a digestibilidade da gordura da dieta pode ser aumentada pela adição de Cu na mesma. Da mesma forma, Luo \& Dove (1996) investigaram o efeito da adição de $\mathrm{Cu}$ (15 e 250 ppm) em dietas contendo 0 ou $5 \%$ de gordura animal sobre a utilização de nutrientes, a atividade de enzimas digestivas e níveis minerais no tecido. Obtiveram como resultados que a adição de 250 ppm de Cu estimulou a atividade da lipase e fosfolipase A no intestino delgado melhorando a utilização da gordura, e conseqüentemente, aumentando a absorção de ácidos graxos e vitaminas lipossolúveis e afetando outros aspectos do metabolismo de nutrientes no corpo. Esses resultados indicam que a melhora no desempenho é devido ao aumento da utilização de gordura, confirmando que a função promotora de crescimento do Cu é sistêmica e, não apenas limitada aos efeitos intestinais.

\section{c) Efeito no controle de doenças}

Este modo de ação é provavelmente o mais amplamente aceito para explicar como os agentes antimicrobianos melhoram 0 crescimento nos animais. Suínos e outros animais são continuamente expostos a ambientes contaminados que causam graus de doenças subclínicas não específicas, reduzindo então o desempenho do animal. Mesmo na ausência de qualquer doença identificável, ou seja, sem que os animais exibam sinais clínicos da doença, presume-se que o acúmulo de 
microrganismos no ambiente determine uma depressão no desempenho animal. Agindo sobre os microrganismos, os agentes antimicrobianos promoveriam um aumento no ganho de peso e na eficiência alimentar. As maiores evidências que confirmam esse mecanismo de ação, é que a resposta aos antimicrobianos é maior em suínos jovens, uma vez que a sua proteção imunológica é baixa; e também é influenciada pela higiene do meio em que os animais estão alojados e pelo seu estado de saúde (Cromwell, 1991).

Hill et al.(1953) conduziram experimentos nos quais dietas com ou sem antibióticos foram fornecidas a grupos de aves em dois tipos de instalações, uma que tinha sido utilizada por muitos anos e a outra recém construída e nunca utilizada. As respostas de crescimento ao agente antimicrobiano foram muito maiores nos aviários velhos do que nos novos, e reforça a teoria de que o estímulo de crescimento em aves obtido pela alimentação de agentes antibacterianos pode ser atribuído à eliminação de infecções.

Concordando com o exposto acima, Visek (1978) especula que os agentes antibacterianos são geralmente promotores de crescimento mais efetivos em instalações com pouca higiene do que em ambientes limpos e isolados; e que, tais agentes no alimento melhoram a capacidade dos animais a adaptar-se ao manejo da criação e a superar o estresse do transporte e do meio em que vivem.

O alto desafio microbiano pode ou não resultar em doença clínica, dependendo da patogenicidade dos microrganismos ou da imunocompetência do animal. Porém o estímulo do sistema imune resulta em alterações metabólicas, chamadas de estresse imunológico, que diminuem a eficiência de utilização de nutrientes para ganho de peso. $O$ 
principal mediador dessas modificações metabólicas è a interleucina-1 plasmática (Klasing et al., 1987).

Roura et al. (1992) observaram que aves criadas em ambiente contaminado e não suplementadas com antibióticos apresentaram menores taxas de ganho de peso e eficiência alimentar e maiores níveis de interleucina-1 plasmática, comparadas com aquelas criadas em ambiente limpo ou aquelas criadas em ambiente contaminado recebendo suplementação de antibióticos. A adição de antibióticos na dieta de aves criadas em ambiente limpo não afetou qualquer variável. Estes resultados indicam que a alimentação com antibióticos estimula o crescimento pela prevenção de estresse imunológico associado a mudanças metabólicas provocadas principalmente pela interleucina-1.

\subsubsection{Biodisponibilidade de Cu das fontes mais comuns}

O sulfato cúprico é a fonte de Cu mais utilizada nas rações de frangos de corte como promotor de crescimento. Muitas vezes, os óxidos cúpricos são usados por conterem uma maior concentração de $\mathrm{Cu}$ $\left(\mathrm{CuO}-80 \% \mathrm{Cu}\right.$ e $\mathrm{CuO}_{2}-89 \% \mathrm{Cu}$ ) do que o sulfato $\left(\mathrm{CuSO}_{4} .5 \mathrm{H}_{2} \mathrm{O}-25 \%\right.$ $\mathrm{Cu}$ ). Porém em estudos com aves (Ledoux et al., 1987) e suínos (Cromwell et al. 1989), foi observado que o $\mathrm{Cu}$ do CuO é altamente indisponivel.

Ledoux et al. (1987), baseando-se em acúmulos no fígado, observou que o $\mathrm{Cu}$ do $\mathrm{CuO}$ é indisponível para aves, enquanto que o sulfato e o carbonato possuem boa disponibilidade. Embora o $\mathrm{CuO}$ seja 
uma forma mais concentrada de $\mathrm{Cu}$ do que o $\mathrm{CuSO}_{4}$, o Cu na forma óxido é ineficaz como promotor de crescimento. Em experimento com suínos foi observado que essa forma não resultou em aumento de $\mathrm{Cu}$ no fígado, e foi ineficiente como promotor de crescimento. Isto sugere que a solubilidade de $\mathrm{Cu}$ é necessária para o seu efeito promotor de crescimento, provavelmente dentro do intestino, então a biodisponibilidade e a promoção de crescimento estão correlacionadas (Cromwell et al., 1989).

Baker et al. (1991) confirmaram esses resultados quando avaliaram a biodisponibilidade do $\mathrm{Cu}$ (usando-se $0 \mathrm{CuSO}_{4} .5 \mathrm{H}_{2} \mathrm{O}$ como padrão de referência) nas formas de $\mathrm{CuO}, \mathrm{Cu}_{2} \mathrm{O}$ e em um complexo $\mathrm{Cu}-$ lisina. Baseando-se no acúmulo de $\mathrm{Cu}$ no fígado, $\mathrm{Cu}_{2} \mathrm{O}$ e Cu-lisina forneceram $\mathrm{Cu}$ tão eficientemente quanto $0 \mathrm{CuSO}_{4} .5 \mathrm{H}_{2} \mathrm{O}$, porém o CuO não supriu Cu disponivel para as aves.

Aoyagi \& Baker (1993) observaram que a fonte Cu-lisina teve um valor de eficácia de $120 \%$, mas não foi diferente do padrão $\left(\mathrm{CuSO}_{4} .5 \mathrm{H}_{2} \mathrm{O}\right)$, o qual era $100 \%$, em dietas de aves. Por outro lado, Zhou et al. (1994b) observaram que o Cu-lisina é um promotor de crescimento mais eficiente do que o sulfato cúprico. Embora sua natureza química seja desconhecida, o Cu-lisina é um quelato com uma taxa de 1:2 de Cu:lisina. Foi observado que o ligante lisina melhora o efeito do $\mathrm{Cu}$ e seus beneficios adicionais apresentaram-se com um aumento no consumo alimentar e um estímulo ao hormônio de crescimento (GH). 


\subsection{Citrato cúprico}

Pesti \& Bakalli (1996) conduziram uma série de experimentos para confirmar alguns dos resultados da utilização de altos níveis de $\mathrm{Cu}$ na dieta de frangos de corte como promotores de crescimento. Utilizaram como fontes de $\mathrm{Cu}$, o sulfato cúprico pentahidratado e o citrato cúprico, e observaram que os animais suplementados com citrato cúprico apresentaram uma melhor resposta no ganho de peso $(5,52 \%)$ e na conversão alimentar $(4,0 \%)$ do que os suplementados com o sulfato pentahidratado. Diversos ensaios foram conduzidos para confirmar a hipótese de que o citrato cúprico é mais eficiente promotor de crescimento do que o sulfato cúprico. Os autores obtiveram como resultados que o citrato cúprico a 63 ou $75 \mathrm{ppm}$ de $\mathrm{Cu}$ apresentou as melhores respostas de crescimento, tendo uma maior eficiência que o sulfato cúprico a 200 pm de $\mathrm{Cu}$.

Confirmando os resultados anteriores, Ewing et al. (1997) verificaram que frangos de corte recebendo uma dieta à base de milho $\mathrm{e}$ farelo de soja suplementada com sulfato cúprico pentahidratado, oxicloreto cúprico e citrato cúprico a $125 \mathrm{ppm}$ de $\mathrm{Cu}$, apresentaram aumento significativo no crescimento e a resposta do citrato cúprico foi significativamente melhor do que das outras fontes testadas. Com a redução do nível de citrato cúprico para $63 \mathrm{mg} / \mathrm{kg}$ de $\mathrm{Cu}$ as aves apresentaram um aumento de ganho de peso de $9,1 \%$, enquanto que o sulfato cúprico pentahidratado e o oxicloreto cúprico aumentaram o ganho em $4,9 \%$.

$\mathrm{O}$ citrato cúprico $\left(\mathrm{C}_{6} \mathrm{H}_{4} \mathrm{Cu}_{2} \mathrm{O}_{7}\right)$ é uma forma orgânica do $\mathrm{Cu}$ também chamado cuprocitol. É preparado pela interação de soluções 
aquosas quentes de $\mathrm{CuSO}_{4}$ e citrato de sódio. Possui um peso molecular de 315,18 com $22,86 \%$ de $\mathrm{C}, 1,28 \%$ de $\mathrm{H}, 35,53 \%$ de $\mathrm{O}$ e $40,32 \%$ de $\mathrm{Cu}$ (tipo Anidro) ou $35,0 \%$ de $\mathrm{Cu}$ (tipo Hemipentahidratado). Principais características: cor verde ou verde-azulada, inodoro, pó cristal, solúvel em água e amônia. Normalmente utilizado como adstringente e antisséptico (The Merck Index, 1989).

Stetsenko et al. (1985) estudaram a absorção de diversas fontes de $\mathrm{Cu}$ in vitro utilizando segmentos de intestino delgado de leitões, e observaram que a absorção do $\mathrm{Cu}$ do citrato cúprico, metioninato cúprico, acetato cúprico, cloreto cúprico e sulfato cúprico foi, respectivamente, $9,7 \%, 8,9 \%, 8,4 \%, 6,8 \%$ e $6,5 \%$ da dose.

Segundo Pesti \& Bakalli (1996), uma das explicações para a razão do $\mathrm{Cu}$ orgânico do citrato cúprico ser mais eficaz que o sulfato cúprico inorgânico é que o citrato cúprico deve ser melhor absorvido do que o sulfato, ou mesmo, ser um melhor cofator para um dos mecanismos pelos quais o Cu promove o crescimento.

\subsection{Resíduos de cobre}

O crescimento da indústria de frangos de corte tem resultado na produção de grandes quantidades de esterco de frango e cama usada. A cama de frango é uma mistura constituída de substrato (comumente chamado cama), de fezes, de penas de aves e de restos de ração. Os tipos de substratos mais recomendados têm sido: sabugo de milho triturado, maravalha de madeira, palhas de arroz, soja ou feijão 
desintegrados, e uma das mais utilizadas é a de maravalha de madeira, devido a sua disponibilidade. A composição química da cama varia de acordo com o tipo de substrato, número de aves $/ \mathrm{m}^{2}$, tipo de alimentação, manejo e tempo de armazenagem. Além disso, a altura da cama (substrato) influencia significativamente em sua composição química (Tiesenhausen, 1985; Vest e Dyer, 1993).

A cama de frango apresenta uma boa aceitabilidade pelos animais e é normalmente usada como fonte de proteína nas dietas de bovinos e ovinos, como substituto principalmente dos farelos de algodão e de soja. Diversos pesquisadores demonstraram que bovinos alimentados com cama de frango ou farelo de soja tiveram ganho e eficiência alimentar similares (Kunkle et al., 1981; Tiesenhausen, 1985).

Além de seu uso na alimentação animal, a cama de frango também é utilizada como fertilizante na agricultura. Normalmente, nos EUA o manejo da cama caracteriza-se pela remoção de uma ou duas vezes por ano da cama dos aviários e dispersão nas pastagens como fertilizante (Smith et al., 1992). O teor de nutrientes no esterco animal foi classificado entre as espécies da seguinte forma: frangos > suínos > bovinos, e a eficiência como fertilizante seguiu a mesma ordem (Harada et al., 1993).

De todo $\circ \mathrm{Cu}$ da ração apenas pequena percentagem é absorvida e desta ainda uma grande parte é eliminada pelo líquido biliar e pela urina, indo para o esterco. Devido à digestão dos alimentos pelo animal, o teor de $\mathrm{Cu}$ no esterco seco é aproximadamente cinco vezes mais alto do que aquele da ração. Por essa razão, o uso do Cu na alimentação de aves deve ser minimizado, visando reduzir resíduos deste 
mineral na cama que, posteriormente servirá como fertilizante (Andriguetto et al., 1990).

Fisher et al. (1973) verificaram progressivos aumentos na quantidade de Cu na cama de frangos suplementados com 200 ppm de sulfato cúprico na dieta. Os níveis de $\mathrm{Cu}$ na dieta e na cama são altamente correlacionados, indicando que o Cu da dieta é concentrado de 2 a 3 vezes nas excretas de frangos e suínos e pode resultar em aumento local das concentrações do mineral no solo e na água. Quando lançado na água ou no solo, o $\mathrm{Cu}$ das excretas pode afetar adversamente o crescimento de organismos aquáticos ou a produção vegetal (Davis, 1974).

Webb \& Fontenot (1975) avaliaram o grau de contaminação da cama de frango por resíduos de drogas, e observaram que os resíduos de $\mathrm{Cu}$ na cama foram maiores quando o sulfato cúprico foi usado na dieta. Foram encontrados uma média de resíduos de 254,7 ppm na cama de aves alimentadas com sulfato cúprico, em contraste com 50,8 ppm quando o sulfato cúprico não foi utilizado.

A utilização contínua de esterco de perus como fertilizante, quando alimentados com uma dieta contendo 120 ppm de $\mathrm{Cu}$, poderá tornar-se um sério risco ao meio ambiente. Foi estimado que a aplicação anual de 8 ton/acre de cama no solo poderá ser tolerada somente por cerca de 10 anos. Depois desse tempo, o íon $\mathrm{Cu}$ poderá vir a ser tóxico para as plantas e, particularmente os ovinos poderão ser sensiveis às forragens produzidas desse modo (Guenthner et al. 1978).

Kunkle et al. (1981) ao estudarem os niveis de arsênico, $\mathrm{Cu}$ e metais pesados em camas de frango reutilizadas em vários lotes, 
verificaram um aumento na concentração de Cu na cama até o terceiro lote e depois um declínio.

Smith et al. (1992) observaram que niveis de $\mathrm{Cu}$ foram levemente menores nos solos fertilizados com cama de frango e maiores nas forragens produzidas nas mesmas. Devido aos altos níveis de $\mathrm{Cu}$ na cama utilizada como fertilizante e ao aumento de produção da forragem com a fertilização, provavelmente o $\mathrm{Cu}$ adicionado ao solo é assimilado pela forragem. Do mesmo modo, Smith et al. (1993) verificaram que forragens produzidas em solos fertilizados com cama de frango apresentaram altos níveis de $\mathrm{Cu}$. Todos os níveis de minerais no esterco fresco ultrapassaram as exigências de bovinos de corte quando a cama constituiu somente $20 \%$ da dieta, além do que foram observados valores de Cu de 3 a 9 vezes do máximo tolerável e 46 a 134 vezes da exigência, em rações de bovinos suplementadas com cama de frango.

Vest \& Dyer (1993) determinaram o grau de concentração de elementos selecionados na cama de frangos sob diversas densidades, e verificaram que o nível médio de Cu na cama foi $50 \%$ maior do que o observado em 1974, provavelmente devido a um aumento de $820 \%$ do nível de Cu na ração de crescimento de frangos de corte de 1977 a 1990.

Kingery et al. (1993) concluíram que o uso por tempo prolongado de cama de frango como fertilizante tem causado um acúmulo de nutrientes no solo e plantas, mas não há evidência que esse acúmulo tenha criado um problema de qualidade nas forragens. Porém, Kingery et al. (1994) verificaram que a aplicação contínua por um longo período de cama de frango sobre o solo alterou suas condições químicas e criou um potencial para impactos ambientais adversos na região onde foi aplicado. 
Diversas pesquisas têm sido feitas para avaliar o nível de Cu na cama de frango utilizada na ração de bovinos e ovinos e seus efeitos sobre estes animais.

A alimentação de ovelhas com cama de frangos contendo altos resíduos de $\mathrm{Cu}$ tem resultado em toxicidade pelo $\mathrm{Cu}$, enquanto que vacas alimentadas com dietas contendo $80 \%$ de cama com altos resíduos de $\mathrm{Cu}$ não apresentaram nenhum efeito adverso ao alto consumo desse mineral. Esta diferença entre estas duas espécies na resposta ao Cu é devido ao fato de que bovinos são menos sensíveis à dieta com $\mathrm{Cu}$ do que os ovinos. Níveis de $\mathrm{Cu}$ nas plantas podem ser maiores que aqueles que causam danos aos ovinos, mas a ausência de adequados niveis de Mo na dieta parece ser um pré-requisito para a produção de intoxicação por Cu nesta espécie ( Davis, 1974; Webb \& Fontenot, 1975).

Ryssen et al. (1977) concluíram que a adição de sulfato cúprico na ração de frangos de corte produz excrementos potencialmente tóxicos para ovinos, enquanto que Miller \& Nelson (1978) observaram sinais clinicos de intoxicação por $\mathrm{Cu}$ em ovelhas alimentadas com pasto fertilizado com cama de frango.

Westing et al. (1985) determinaram o efeito da suplementação de cama de frango ensilada na dieta de bezerros desmamados sobre os níveis de minerais nos diferentes tecidos, e observaram que nenhuma diferença foi encontrada na qualidade de carcaça e qualidades organolépticas da carne, e que, o modesto aumento no tecido de certos elementos químicos não representou sério risco para a saúde humana.

Banton et al. (1987) estudaram a toxicidade do Cu na cama de frango utilizada na alimentação de bovinos, e observaram que alguns 
animais desenvolveram sinais de intoxicação. Resultados de análises do Cu na cama indicaram uma média de 620 a 920 ppm; enquanto Canton et al. (1994) estimaram os danos causados pelo $\mathrm{Cu}$ contido na cama de frango na alimentação de ovelhas, e concluíram que o Cu na cama de frangos é potencialmente tóxico para ovelhas.

Como o citrato cúprico pode ser usado em níveis menores que o sulfato cúprico, há uma redução de resíduos de Cu na cama quando o citrato cúprico é utilizado como promotor de crescimento para frangos de corte, diminuindo os riscos de poluição ambiental e/ou intoxicação de animais (Pesti \& Bakalli, 1996). 


\section{MATERIAL E MÉTODOS}

\subsection{Materiais:}

\subsubsection{Animais:}

Foram utilizados 1.200 pintos de corte machos, da linhagem "Ross", com um dia de idade, autosexáveis pelas asas, provenientes do incubatório da Pena Branca localizado no município de São Carlos, Estado de São Paulo. Ao nascer, foram vacinados contra a Doença de Marek e Gumboro (via intramuscular) e contra Bronquite Infecciosa (spray).

\subsubsection{Rações Experimentais:}

A ração basal utilizada durante o periodo experimental foi dividida em três tipos de acordo com as exigências nutricionais das seguintes fases da criação: inicial (1 a 21 dias), crescimento (22 a 35 dias) e final (36 a 42 dias). As rações foram formulada à base de milho e 
farelo de soja seguindo as recomendações de Rostagno et al. (1994), utilizando-se o programa "Sistema conversacional para minimização do custo da ração" de Gomide e Rostagno. Foram produzidas na Fábrica de Rações do Departamento de Zootecnia da ESALQ/USP, setor de Não Ruminantes. As formas de cobre adicionadas às rações basais foram citrato cúprico anidro $(37,38 \%$ de $\mathrm{Cu})$ e sulfato cúprico pentahidratado (25\% de $\mathrm{Cu})$.

Foram realizadas análises bromatológicas do milho e farelo de soja utilizados nas rações experimentais no Laboratório de Bromatologia do Departamento de Zootecnia da ESALQ/USP, em Piracicaba, São Paulo. Os resultados das análises estão na Tabela 1.

Tabela 1: Resultados de análise do milho e do farelo de soja utilizados na ração basal.

\begin{tabular}{lcc}
\hline \multicolumn{1}{c}{$\%$} & MILHO & FARELO DE SOJA \\
\hline Matéria Seca & 89,41 & 90,51 \\
Proteína Bruta & 7,64 & 44,15 \\
Fibra Bruta & 2,67 & 5,56 \\
Extrato Etéreo & 3,36 & 0,70 \\
Matéria Mineral & 1,14 & 6,28 \\
Extrativo Não Nitrogenado & 74,59 & 33,82 \\
\hline
\end{tabular}

A composição percentual e valores calculados das dietas basais estão na Tabela 2 . 
Tabela 2. Composição percentual e valores calculados das dietas basais.

\begin{tabular}{lccc}
\hline \multicolumn{1}{c}{ INGREDIENTE } & INICIAL & CRESCIMENTO & FINAL \\
\hline Milho & 57,320 & 62,455 & 64,820 \\
Farelo de Soja & 36,535 & 32,046 & 29,428 \\
Oleo Vegetal & 2,298 & 2,053 & 2,388 \\
Fosfato Bicálcico & 1,953 & 1,739 & 1,754 \\
Calcário & 1,123 & 1,024 & 1,039 \\
DL-Metionina 99\% & 0,161 & 0,123 & 0,110 \\
Sal. & 0,300 & 0,300 & 0,300 \\
Cloreto de Colina 60\% & 0,080 & 0,040 & 0,020 \\
Premix Vitamínico $^{\mathrm{a}}$ & 0,120 & 0,100 & 0,080 \\
Premix Mineral $^{\mathrm{b}}$ & 0,060 & 0,060 & 0,060 \\
Agente anticoccidiano & $0,050^{\mathrm{c}}$ & $0,060^{\mathrm{d}}$ & - \\
\hline
\end{tabular}

\section{VALORES CALCULADOS}

\begin{tabular}{lccc}
\hline Proteína Bruta, \% & 21,63 & 20,00 & 19,00 \\
Metionina, \% & 0,49 & 0,44 & 0,41 \\
Met + Cistina, \% & 0,85 & 0,77 & 0,73 \\
Lisina, \% & 1,10 & 0,99 & 0,93 \\
Cálcio, \% & 1,00 & 0,90 & 0,90 \\
Fósforo disponível, \% & 0,45 & 0,41 & 0,41 \\
Energia Metabolizável, kcal/kg & 3.000 & 3.050 & 3.100 \\
\hline
\end{tabular}

${ }^{a}$ Cada kg do premix vitamínico contém: vit. A, 10.000 .000 Ul; vit.D3, 2.000.000 Ul; vit. $E$, $30.000 \mathrm{mg}$; vit. $K 3,3.000 \mathrm{mg}$; vit.B1, $2.000 \mathrm{mg}$; vit. B2, $6.000 \mathrm{mg}$; vit.B6, $4.000 \mathrm{mg}$; vit. B12, $15.000 \mathrm{mcg}$; ácido fólico, $1.000 \mathrm{mg}$; ácido Pantotênico, $12.000 \mathrm{mg}$; ácido Nicotínico, 50.000 $\mathrm{mg}$; Se, $250 \mathrm{mg}$.

${ }^{b}$ Cada $\mathrm{kg}$ do premix mineral contém: $\mathrm{Mn}, 16.000 \mathrm{mg} ; \mathrm{Cu}, 20.000 \mathrm{mg} ; \mathrm{Zn}, 100.000 \mathrm{mg}$; Fe, $100.000 \mathrm{mg} ; \mathrm{I}, 2.000 \mathrm{mg}$;

${ }^{c}$ Anticoccidiano utilizado: maduramicina $0,75 \%$ + nicarbazina $8,0 \%$.

Anticoccidiano utilizado: lasalocida sódica $15 \%$. 


\subsubsection{Citrato Cúprico:}

$\mathrm{O}$ citrato cúprico $\left(\mathrm{C}_{6} \mathrm{H}_{4} \mathrm{Cu}_{2} \mathrm{O}_{7}\right)$ utilizado na dieta experimental foi cedido pela Griffin Corporation, em Valdosta, Georgia, USA. De acordo com as análises realizadas através de espectofotometria por absorção atômica pelo Laboratório de Controle de Qualidade da SUPREMAIS Produtos Bioquímicos Ltda., em Valinhos, São Paulo, 0 citrato era do tipo Anidro e continha $37,38 \%$ de $\mathrm{Cu}$.

\subsubsection{Instalaçōes e Equipamentos:}

O experimento foi realizado no aviário experimental do Departamento de Zootecnia da Escola Superior de Agricultura "Luiz de Queiroz", no município de Piracicaba, Estado de São Paulo.

O aviário experimental (Figura 1) possui $32 \mathrm{~m}$ de comprimento por $8 \mathrm{~m}$ de largura, com mureta lateral de alvenaria de 0,6 m de altura completada com tela de arame, piso de concreto, cobertura de telhas de barro tipo francesa e duas portas de acesso nas extremidades. É constituído de 30 divisões (boxes) dispostos em três fileiras longitudinais, cada fileira contendo 10 "boxes", separados umas das outras por um corredor com 1,0 m de largura. Cada "box" possui uma área de $2,5 \times 2,0 \mathrm{~m}$ e são separados por tábuas com $0,3 \mathrm{~m}$ de altura completadas com tela de arame de 1,70 m de altura (Figura 2).

A iluminação artificial do aviário foi feita por 11 lâmpadas incandescentes de 60 watts cada, dispostas na parte central a uma altura de 2,30 metros do piso. 
Os equipamentos utilizados durante o período experimental foram: lâmpadas infravermelhas de 250 watts, em número de uma por "box", a 0,60 metros do piso para o aquecimento inicial dos pintos; bebedouros tipo pendular, em número de um por "box"; comedouros tipo bandeja para a primeira semana, e pendular com capacidade de $25 \mathrm{~kg}$ a partir da segunda semana, em número de um por "box"; cortinas de polietileno dos dois lados do galpão; balanças eletrônicas com capacidade para $15 \mathrm{~kg}$ e $150 \mathrm{~kg}$ utilizadas na pesagem dos frangos e da ração e termômetro de máxima e mínima.

A cama utilizada foi a casca de arroz, com espessura média de $4,0 \mathrm{~cm}$.

\subsubsection{Periodo Experimental:}

O período total do experimento foi de 42 dias (06/11/97 a 17/12/97), em que foi testado um determinado nível de citrato cúprico nas seguintes fases de criação: 1 a 21, 22 a 42 e 1 a 42 dias. Houve uma dieta basal (controle negativo) e uma dieta suplementada com sulfato cúprico pentahidratado (controle positivo) para melhor avaliação dos efeitos do citrato cúprico. 


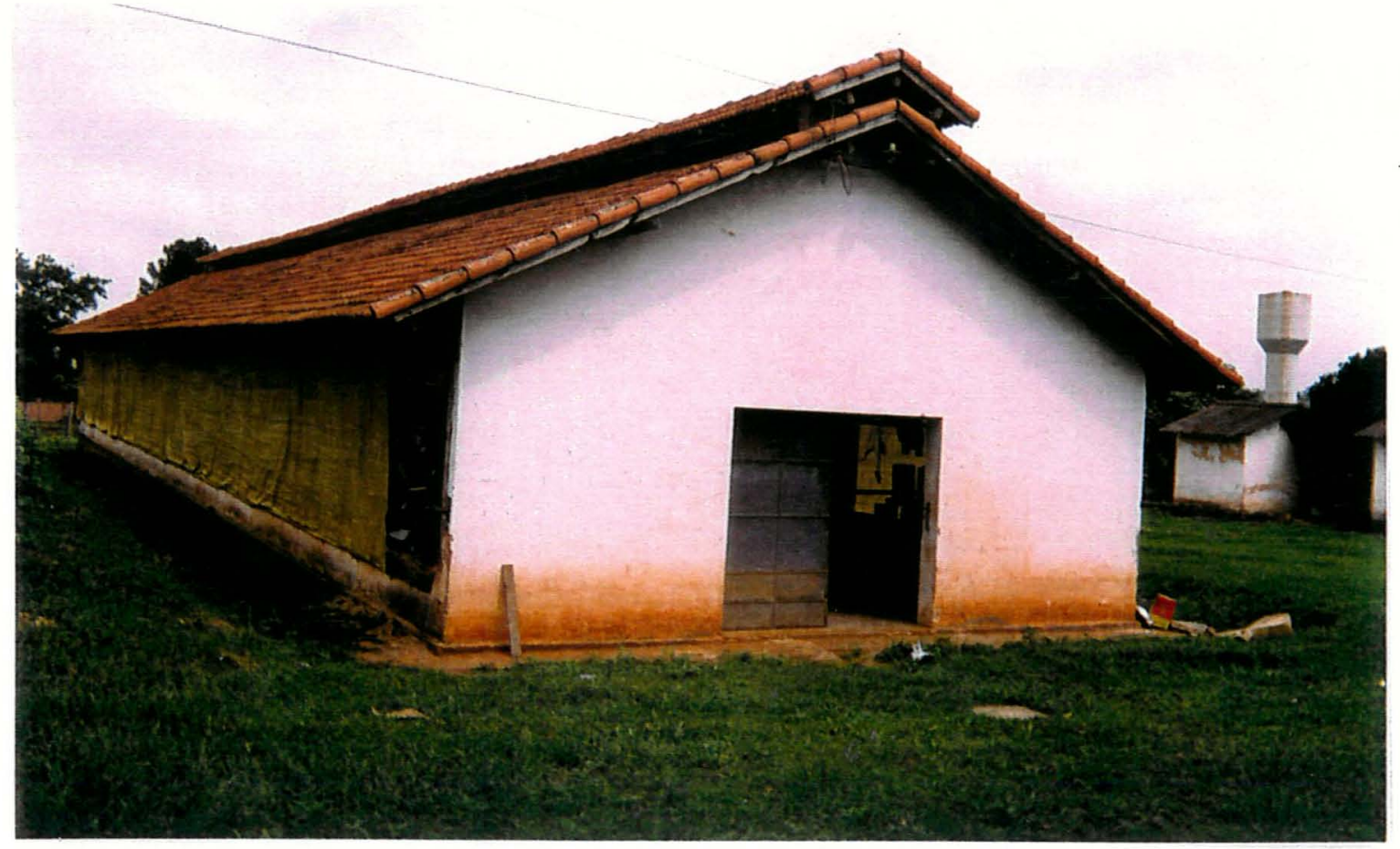

Figura 1. Vista externa do aviário experimental.

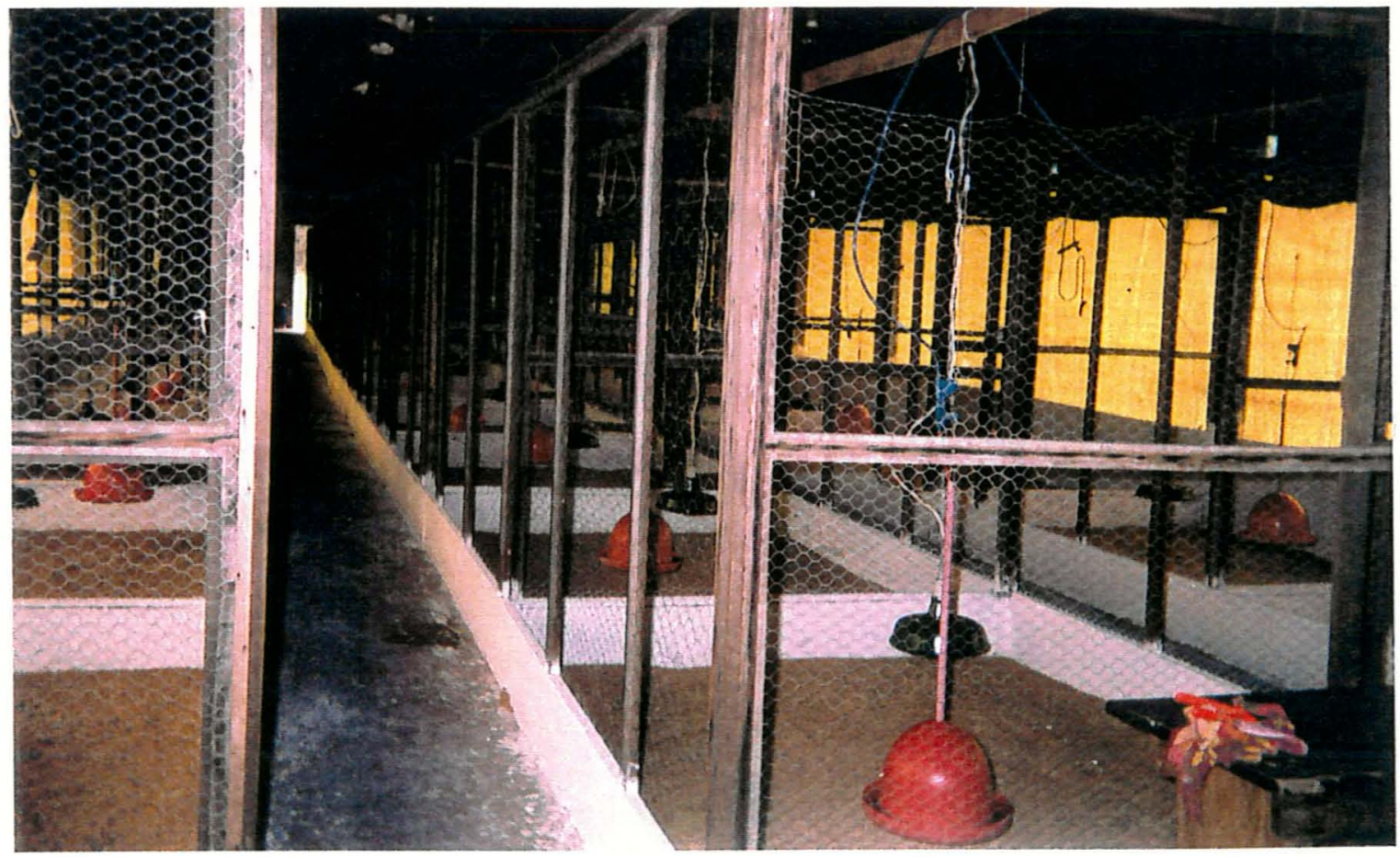

Figura 2. Vista interna do aviário experimental e suas divisões. 


\subsection{Métodos:}

\subsubsection{Preparação das instalações e equipamentos para 0 recebimento dos pintos:}

Antes do início do período experimental as instalações e equipamentos passaram por uma série de medidas higiênicas a fim de garantir um bom controle sanitário evitando problemas de desempenho no lote.

Uma semana antes do recebimento dos pintos o aviário foi espanado e varrido, tanto as telas e cortinas, como o piso. Em seguida foi lavado com água sob pressão (jato d'água), incluindo o telhado, paredes, cortinas, piso e equipamentos. A caixa d'água, as tubulações e as mangueirinhas dos bebedouros pendulares foram lavadas e depois desinfectadas com iodo (Biocid) na diluição de 1:1200 litros. A desinfecção do aviário e equipamentos foi feita com iodo na diluição de 1:500 litros através de pulverização com bomba costal com capacidade de 20 litros.

Após a lavagem e desinfecção, as cortinas do galpão foram fechadas para um descanso sanitário de alguns dias. Nesse periodo foram feitos alguns reparos e pintura com cal nas tábuas de separação dos "boxes", colocação da cama de casca de arroz nos "boxes" e regulagem dos equipamentos (comedouros, bebedouros e lâmpadas de aquecimento) para o recebimento dos pintos.

Pouco antes da chegada dos pintos as lâmpadas de aquecimento foram acesas e os bebedouros abastecidos com água fresca 
contendo um complexo vitamínico (Vitagold Potenciado), o qual foi diluído a $2 \mathrm{ml} /$ litro diretamente na caixa d'água.

\subsubsection{Condução do Experimento:}

Ao chegarem ao aviário, as aves foram pesadas $e$ distribuídas ao acaso entre os 30 "boxes" (40 aves/parcela). Logo depois, os comedouros tipo bandeja foram abastecidos com ração inicial já pesada para o controle do consumo. Nas primeiras semanas do experimento, foram utilizadas as lâmpadas de aquecimento $e$ os comedouros tipo bandeja. As lâmpadas de aquecimento permaneceram acesas por 24 horas diárias até o $5^{0}$ dia, sendo então ligadas somente à noite e foram retiradas definitivamente quando as aves completaram 21 dias de vida.

A ração foi administrada em bandejas até o 8ํำ dia, a partir daí então foram mantidos apenas os comedouros tubulares. Os bebedouros pendulares permaneceram no "box" durante todo o período experimental e eram lavados duas vezes ao dia. Foram fornecidas ração e água à vontade

O aviário recebeu iluminação constante ( $24 \mathrm{~h}$ de luz) e o manejo da cortina foi realizado nas primeiras semanas e nos períodos mais frios, quando permaneciam levantadas. A temperatura foi monitorada diariamente através de um termômetro de máxima e de mínima localizado no centro do aviário e à altura de $0,2 \mathrm{~m}$ do piso. As temperaturas eram registradas sempre às 9:00 h da manhã (Apêndices 1 e 2). 
As aves foram vacinadas no $12^{0}$ dia do experimento contra a Doença de Newcastle (amostra B1) e Gumboro (cepa intermediária) na água de bebida na diluição de 1.000 doses em 11 litros d'água.

Foram feitas pesagens semanais coletivas de cada grupo das parcelas em engradados de plástico utilizando-se balança eletrônica com capacidade de $15 \mathrm{~kg}$ e precisão de $0,01 \mathrm{~kg}$ na primeira pesagem e balança eletrônica com capacidade de $150 \mathrm{~kg}$ e precisão de $0,1 \mathrm{~kg}$ nas demais pesagens. Toda a ração fornecida às aves era pesada antes da administração aos comedouros, como também as sobras ao final de cada semana. A mortalidade era registrada diariamente e as aves retiradas do "box" logo após a observação.

Foram coletadas amostras de cama no início (duas) e no final do experimento (30) para análise de resíduos de cobre. Durante a fase experimental, não houve remoção de partes úmidas da cama, fazendo quando necessário uma adição de fina camada de cama seca embaixo e ao redor dos bebedouros. Este manejo foi realizado aos 28, 35 e 39 dias do experimento.

Também houve coleta de uma amostra de água dos bebedouros para análise de $\mathrm{Cu}$, a qual foi armazenada sob refrigeração para posterior análise. De acordo com análises pelo método de espectofotometria por absorção atômica realizadas pelo Laboratório de Controle de Qualidade da SUPREMAIS Ltda. em Valinhos, São Paulo foram detectados apenas traços de $\mathrm{Cu}$ (menos de 0,05 ppm). 


\subsubsection{Delineamento experimental:}

O delineamento experimental foi em blocos ao acaso, com cinco tratamentos e seis repetições perfazendo um total de 30 parcelas experimentais. Cada parcela experimental possuía no início 40 aves, totalizando 1.200 aves. Os blocos constituíram-se de um grupo de cinco "boxes" (dois blocos em cada uma das três fileiras longitudinais), totalizando seis blocos.

$$
\begin{aligned}
& \text { O modelo estatístico considerado foi: } \\
& \begin{array}{ll}
X_{i j}=m+t_{i}+b_{j}+e_{i j} & i=1,2,3,4,5 \\
& j=1,2,3,4,5,6
\end{array}
\end{aligned}
$$

em que:

$X_{i j}=$ valor observado na parcela que recebeu o tratamento i e se encontra no bloco j;

$\mathrm{m}$ = média da população;

$t_{i}=$ efeito devido ao tratamento $i$, que foi aplicado na parcela;

$b_{j}=$ efeito devido ao bloco j, em que se encontra a parcela;

$e_{i j}=$ efeito devido aos fatores não controlados, na parcela.

Os tratamentos foram distribuídos por sorteio dentro de cada bloco e foram constituídos por:

- Controle - dieta basal contendo $12 \mathrm{mg} / \mathrm{kg}$ de $\mathrm{Cu}$;

- Citrato 1-21 - dieta basal + citrato cúprico $(75 \mathrm{mg}$ de $\mathrm{Cu} / \mathrm{kg})$ durante o período de 1 a 21 dias e dieta basal durante o periodo de 22 a 42 dias; 
- Citrato 22-42 - dieta basal durante o período de 1 a 21 dias e dieta basal + citrato cúprico $(75 \mathrm{mg}$ de $\mathrm{Cu} / \mathrm{kg})$ durante o período de 22 a 42 dias;

- Citrato 1-42 - dieta basal + citrato cúprico (75 mg de Cu/kg) durante o periodo de 1 a 42 dias;

- Sulfato - dieta basal + sulfato cúprico pentahidratado $(200 \mathrm{mg}$ de $\mathrm{Cu} / \mathrm{kg}$ ) durante o periodo de 1 a 42 dias.

Foram analisadas as seguintes variáveis nos períodos testados ( 1 a 21,22 a 42 e 1 a 42 dias):

- Peso vivo médio;

- Ganho médio em peso;

- Consumo alimentar médio;

- Conversão alimentar média;

- Mortalidade;

- Resíduos de Cu na cama (apenas aos 42 dias do experimento).

\subsubsection{Obtenção dos Dados:}

O peso vivo médio (PVM) foi obtido pela razão entre o peso vivo total da parcela e o número de aves sobreviventes.

O ganho médio em peso (GMP) foi estimado diminuindo-se o peso médio semanal do peso médio da semana anterior.

O consumo alimentar médio (CONS) foi avaliado subtraindo-se o total de ração fornecida ao grupo na semana da sobra dos comedouros no final da mesma, e dividindo-se pelo número de aves da parcela. Semanalmente era feita uma correção do consumo de cada 
parcela, levando-se em consideração o número de mortos e o dia de sua retirada do grupo. Fórmula da correção do consumo:

CONS corrigido $=$ CONS total $\div$ (dia da fase em que ocorreu a morte $X n^{0}$ de aves + dias restantes da fase $X n^{0}$ de aves sobreviventes) $\times n^{0}$ de dias da fase

A conversão alimentar média (CA) foi obtida dividindo-se o consumo alimentar médio corrigido da parcela pela média de ganho de peso correspondente.

A mortalidade (MORT) era registrada logo após a observação e as aves mortas retiradas do "box". Até o $5^{\underline{0}}$ dia do experimento os pintos mortos e "refugos" foram substituídos, de modo que a contagem da mortalidade teve início após esse dia. A ocorrência de aves "refugos" foi mínima, fazendo-se a retirada dessas aves durante as pesagens semanais e considerando-se como mortalidade.

Os resíduos de $\mathrm{Cu}$ na cama (RES) foram avaliados pela análise do micromineral em amostras de cama de todos os "boxes".

\subsubsection{Coleta e análise das amostras de cama:}

Após a retirada dos frangos ao término do período de 42 dias do experimento, todos os "boxes" tiveram a cama revirada e homogeneizada para garantir a uniformidade das amostras. Foram coletadas amostras de cama de diferentes pontos de cada "box" e acondicionadas em saco plástico devidamente identificado com o número do "box". A coleta foi realizada manualmente com a utilização de luvas de borracha. 
Depois da coleta, um total de 32 amostras de cama (30 amostras coletadas no final do experimento e duas amostras de casca de arroz coletadas no início) foram levadas ao Laboratório do Departamento de Ciência do Solo da ESALQ/USP, em Piracicaba, São Paulo, onde foram armazenadas sob refrigeração para posterior análise.

Foram realizadas análises de $\mathrm{Cu}$ em material orgânico nas amostras de cama através do método de espectofotometria por absorção atômica. Segundo a metodologia, o material foi queimado a $500^{\circ} \mathrm{C}(1 \mathrm{~g})$, colocado em um becker onde fez-se a extração com ácido clorídrico $(\mathrm{HCl})$ na diluição de $1+1$, e depois realizada a leitura por absorção atômica.

\subsubsection{Análise dos Resultados:}

Os dados obtidos no experimento foram tabulados em planilha de Excel 7.0 e analisados no programa SAS (Statistical Analyses System) de análises estatísticas.

Os dados de desempenho (PVM, GMP, CONS, CA e MORT) foram submetidos à análise de variância nos períodos 1 a 21 dias, 22 a 42 dias e 1 a 42 dias e suas médias comparadas através do teste de Tukey. Foram feitas comparações através de contrastes envolvendo os tratamentos agrupados em: a) DB (controle e citrato 22-42), b) citrato (citrato 1-21 e citrato 1-42), c) sulfato (sulfato) no periodo de 1 a 21 dias e d) DB (controle), e) citrato (citrato 1-21, citrato 22-42 e citrato 1-42), sulfato (sulfato) no período de 1 a 42 dias. Em todos os periodos analisados, os dados de mortalidade foram transformados em arc $\operatorname{sen} \sqrt{\% / 100}$. Os resultados das análises de resíduos de $\mathrm{Cu}$ na cama 
foram submetidos à análise de variância e suas médias comparadas pelo teste de Tukey. 


\section{RESULTADOS E DISCUSSÃO}

\subsection{Peso Vivo Médio (PVM), Ganho Médio em Peso (GMP), Consumo Alimentar Médio (CONS) e Conversão Alimentar (CA):}

As análises de variância para PVM das aves aos 21 e 42 dias de idade encontram-se nos Apêndices 3 e 4.

A Tabela 3 apresenta os resultados obtidos em PVM para frangos de corte submetidos à suplementação na dieta de citrato cúprico em diferentes fases e de sulfato cúprico no periodo total analisados aos 21 e aos 42 dias.

Tabela 3. Efeito dos tratamentos no PVM das aves aos 21 e aos 42 dias de idade.

\begin{tabular}{ccc}
\hline Tratamentos & \multicolumn{2}{c}{ Peso Vivo Médio $\mathbf{~ k g )}$} \\
\hline & 21 dias & 42 dias \\
\cline { 2 - 3 } Controle & 0,775 & 2,427 \\
Citrato 1-21 & 0,793 & 2,443 \\
Citrato 22-42 & 0,785 & 2,421 \\
Citrato 1-42 & 0,760 & 2,438 \\
Sulfato & 0,766 & 2,420 \\
\hline CV $(\%)$ & 2,30 & 1,80 \\
\hline
\end{tabular}

Contrastes: DB vs. Citrato $(P=0,63)$; DB vs. Sulfato $(P=0,12)$; Citrato vs. Sulfato $(P=0,24)$.

2. Contrastes: $D B$ vs. Citrato $(P=0,74) ; D B$ vs. Sulfato $(P=0,78)$; Citrato vs. Sulfato $(P=0,51)$. 
Não houve diferença estatística significativa $(P>0,05)$ entre as médias de PVM dos tratamentos e nem entre os grupos testados (citrato, sulfato e controle) em nenhum dos períodos, indicando que nenhuma das fontes de $\mathrm{Cu}$ testadas apresentaram efeito sobre o PVM das aves suplementadas.

A análise da variável PVM permite um melhor acompanhamento do desempenho da ave pela comparação dos resultados obtidos no experimento com os da tabela de desempenho da linhagem utilizada. O valor de PVM para machos da linhagem Ross aos 42 dias é de 2,425 kg (Agroceres, 1997), que é semelhante aos valores de PVM obtidos no presente experimento. Apesar de não haver diferença estatística entre os tratamentos, o citrato 1-21 apresentou um maior PVM que os demais tratamentos, e o sulfato teve um PVM menor que o controle.

A análise de variância para GMP nos períodos de 1 a 21 dias, 22 a 42 dias e 1 a 42 dias encontram-se nos Apêndices 5, 6 e 7.

A Tabela 4 apresenta os resultados obtidos em GMP para frangos de corte submetidos à suplementação na dieta de citrato cúprico em diferentes fases e de sulfato cúprico no período total analisados no periodo de 1 a 21 dias, de 22 a 42 dias e de 1 a 42 dias. 
Tabela 4. Efeito dos tratamentos no GMP das aves testados nos períodos de 1 a 21 dias, de 22 a 42 dias e de 1 a 42 dias da criação.

\begin{tabular}{cccc}
\hline Tratamentos & \multicolumn{3}{c}{ Ganho Médio em Peso (kg) } \\
\hline & 1 a 21 dias & 22 a 42 dias & 1 a 42 dias $^{2}$ \\
\cline { 2 - 4 } Controle & 0,732 & 1,652 & 2,384 \\
Citrato 1-21 & 0,750 & 1,650 & 2,399 \\
Citrato 22-42 & 0,742 & 1,635 & 2,378 \\
Citrato 1-42 & 0,716 & 1,679 & 2,395 \\
Sulfato & 0,722 & 1,654 & 2,377 \\
\hline CV $(\%)$ & 2,45 & 2,03 & 1,84 \\
\hline
\end{tabular}

Contrastes: DB vs. Citrato $(P=0,60)$; $D B$ vs. Sulfato $(P=0,12)$; Citrato vs. Sulfato $(P=0,24)$.

2 . Contrastes: $D B$ vs. Citrato $(P=0,75) ; D B$ vs. Sulfato $(P=0,77)$; Citrato vs. Sulfato $(P=0,50)$.

Não houve diferença estatística significativa entre as médias de GMP dos tratamentos nos períodos testados $(P>0,05)$ e nem dos grupos comparados (controle, citrato e sulfato) nos períodos de 1 a 21 e 1 a 42 dias de criação ( $P>0,05)$.

A análise de variância nos períodos de 1 a 21 dias, 22 a 42 dias e 1 a 42 dias para CONS encontram-se nos Apêndices 8, 9 e 10.

A Tabela 5 apresenta os resultados obtidos em CONS para frangos de corte submetidos à suplementação na dieta de citrato cúprico em diferentes fases e de sulfato cúprico no período total, analisados no período de 1 a 21 dias, 22 a 42 dias e 1 a 42 dias. 
Tabela 5. Efeito dos tratamentos no CONS das aves testados nos períodos de 1 a 21 dias, de 22 a 42 dias e de 1 a 42 dias da criação.

\begin{tabular}{|c|c|c|c|}
\hline \multirow[t]{2}{*}{ Tratamentos } & \multicolumn{3}{|c|}{ Consumo Médio (kg) } \\
\hline & 1 a 21 dias $^{1}$ & 22 a 42 dias & 1 a 42 dias $^{2}$ \\
\hline Controle & 1,163 & 3,253 & 4,417 \\
\hline Citrato 1-21 & 1,164 & 3,318 & 4,481 \\
\hline Citrato $22-42$ & 1,135 & 3,293 & 4,428 \\
\hline Citrato $1-42$ & 1,123 & 3,313 & 4,436 \\
\hline Sulfato & 1,139 & 3,254 & 4,393 \\
\hline $\mathrm{CV}(\%)$ & 2,00 & 1,98 & 1,42 \\
\hline
\end{tabular}

T. Contrastes: DB vs. Citrato $(P=0,55)$; $D B$ vs. Sulfato $(P=0,40)$; Citrato vs. Sulfato $(P=0,72)$.

2. Contrastes: $D B$ vs. Citrato $(P=0,29) ; D B$ vs. Sulfato $(P=0,52)$; Citrato vs. Sulfato $(P=0,08)$.

Não houve diferença estatística significativa $(P>0,05)$ entre as médias de CONS dos tratamentos em nenhum dos períodos testados através do Teste de média Tukey. Porém, com a análise dos contrastes no período total da criação houve efeito significativo do contraste citrato vs. sulfato $(P=0,08)$ indicando que as aves suplementadas com citrato nas diferentes fases testadas apresentaram um maior CONS do que as aves suplementadas com sulfato.

A análise de variância para CA nos períodos de 1 a 21 dias, de 22 a 42 dias e de 1 a 42 dias encontram-se nos Apêndices 11, 12 e 13. Houve efeito significativo $(P<0,05)$ dos tratamentos sobre a $C A$ no período de 22 a 42 dias.

A Tabela 6 apresenta os resultados obtidos em CA para frangos de corte submetidos à suplementação na dieta de citrato cúprico em diferentes fases e de sulfato cúprico no período total, analisadas no período de 1 a 21 dias, de 22 a 42 dias e de 1 a 42 dias. 
Tabela 6. Efeito dos tratamentos na CA das aves testados nos períodos de 1 a 21 dias, de 22 a 42 dias e de 1 a 42 dias da criação.

\begin{tabular}{|c|c|c|c|}
\hline \multirow[t]{2}{*}{ Tratamentos } & \multicolumn{3}{|c|}{ Conversão Alimentar } \\
\hline & 1 a 21 dias $^{1}$ & 22 a 42 dias & 1 a 42 dias $^{2}$ \\
\hline Controle & 1,591 & $1,969^{\mathrm{ab}}$ & 1,853 \\
\hline Citrato 1-21 & 1,552 & $2,011^{\mathrm{ab}}$ & 1,868 \\
\hline Citrato $22-42$ & 1,530 & $2,014^{a}$ & 1,863 \\
\hline Citrato $1-42$ & 1,570 & $1,973^{\mathrm{ab}}$ & 1,853 \\
\hline Sulfato & 1,579 & $1,967^{b}$ & 1,849 \\
\hline CV $(\%)$ & 3,60 & 1,33 & 1,43 \\
\hline
\end{tabular}

Não houve diferença estatística significativa entre as médias de $\mathrm{CA}$ dos diferentes tratamentos quando os dados foram analisados no período de 1 a 21 e de 142 dias do experimento e nem entre as médias dos diferentes grupos testados (sulfato, citrato e controle) nos mesmos períodos. Porém no período de 22 a 42 dias, observa-se que quando o citrato foi utilizado no período de 22 a 42 dias na dieta das aves que não receberam qualquer suplementação previamente houve uma piora da $C A$, sendo significativamente diferente $(P<0,05)$ apenas da $C A$ do tratamento sulfato.

Os resultados de PMV, GMP, CONS, e CA não estão de acordo com Fisher et al. (1973) e Hoda \& Maha (1995) que verificaram que a adição de altos níveis de várias fontes de Cu na dieta (de 125 a 160 $\mathrm{mg} / \mathrm{kg}$ ), provocou uma melhora significativa no desempenho de frangos de corte. Porém, concordam com os obtidos por Poupolis \& Jensen (1975) que, utilizando 250 ppm de Cu na dieta de frangos de corte apenas 
observaram uma leve melhora no crescimento e eficiência alimentar, mas as diferenças não foram significativas $(P>0,05)$, e não houve qualquer diferença de resposta do Cu no início ou no final da criação.

Pesti \& Bakalli (1996) obtiveram resultados que confirmaram o efeito promotor de crescimento do $\mathrm{Cu}$ na ração de frangos de corte, e observaram que o citrato foi mais eficiente a niveis mais baixos do que o sulfato cúprico. Apesar de ter sido utilizado o mesmo nível de citrato cúprico (75 mg Cu/ $\mathrm{kg}$ ) e de sulfato cúprico (200 mg Cu/ $\mathrm{kg}$ ) com o qual os autores acima obtiveram as melhores respostas de crescimento em seus estudos, não foi observada qualquer diferença de resposta entre o sulfato e o citrato no presente estudo, exceto por um pequeno aumento no CONS das aves suplementadas com citrato.

Ewing et al. (1997) observaram aumentos no ganho de peso de $4,9 \%$ e $9,1 \%$ com a suplementação do sulfato e citrato cúprico, respectivamente, e conversões alimentares $5,2 \%$ e $7,6 \%$ melhores quando comparadas às dietas basais em dois experimentos. Tal melhora no desempenho das aves não foi confirmada no presente estudo.

O sulfato cúprico foi utilizado neste experimento como controle positivo na comparação com os efeitos do citrato cúprico devido aos diversos resultados que comprovaram sua eficácia como promotor de crescimento de frangos de corte. Porém, analisando-se os resultados de PVM e GMP observa-se uma leve piora no desempenho com o uso dessa fonte de Cu quando comparada aos demais tratamentos, inclusive à dieta não suplementada (Controle).

Os mecanismos pelos quais o $\mathrm{Cu}$ promove a melhora do desempenho de aves e suínos não foram totalmente esclarecidos. Diversos autores sugerem que este mineral possui, possivelmente, o 
mesmo modo de ação dos agentes antimicrobianos. Um dos mecanismos apontados como responsável pelos efeitos do $\mathrm{Cu}$ na melhora do desempenho seria sua ação sobre microrganismos causadores de doenças, que mesmo sem apresentar sinais clínicos, podem afetar o crescimento animal (Cromwell, 1991). Uma das maiores evidências que confirmam esse mecanismo de ação é que os agentes antimicrobianos são geralmente mais eficientes como promotores de crescimento em instalações antigas ou com pouca higiene do que em ambientes novos e isolados (Hill et al., 1953; Visek, 1978).

O estímulo do sistema imune resulta em uma alteração metabólica que diminui a eficiência de utilização de nutrientes para ganho de peso, possivelmente por alterações na absorção de nutrientes ou na taxa metabólica. Há diversos mecanismos pelos quais o sistema imune, quando estimulado, pode resultar em mudanças no metabolismo e conseqüente redução no crescimento e eficiência de utilização alimentar, como a interação com glândulas endócrinas aumentando ou diminuindo a liberação de hormônios, ou mesmo, suas próprias células podem liberar seus hormônios que causam as alterações metabólicas. Evidências indicam que o principal mediador envolvido no estresse imune é a interleucina-1. Diversos experimentos comprovaram que os níveis de interleucina-1 aumentaram após um estresse imunológico, além de que, injeções de interleucina-1 resultaram em uma redução no crescimento, na eficiência alimentar e mudanças no metabolismo mineral (Klasing et al., 1987).

Estudos conduzidos por Roura et al. (1992) indicaram que o grau de higiene do ambiente afeta a ação dos antibióticos na promoção do crescimento, pois a habilidade de tais aditivos na melhora do 
desempenho de aves depende da extensão do desafio microbiano. Em ambientes limpos, o ganho de peso e a eficiência alimentar de aves suplementadas com antibiótico foram similares aos daquelas que não receberam suplementação na dieta. Como a intensidade do desafio diminui em um ambiente limpo, houve uma redução do efeito positivo dos antibióticos sobre o crescimento em tais ambientes. Porém, em um ambiente com pouca higiene, o aumento da taxa de crescimento e da eficiência alimentar devido aos antibióticos foram acompanhados pela redução dos níveis de interleucina circulante, o que sugere que os antibióticos reduzem o estresse imunológico.

Esse mecanismo de ação dos agentes antimicrobianos no controle de doenças pode ter grande relação com os resultados do presente estudo, pois a cuidadosa desinfecção das instalações e equipamentos antes do recebimento dos pintos e 0 ambiente relativamente livre de desafio microbiano devido aos cuidados de manejo e do isolamento das instalações, indicam as ótimas condições higiênicas na condução do experimento. Além disso, durante o experimento a taxa de mortalidade e aves "refugos" foi baixa (aproximadamente 1,67\%), o que confirma o bom estado sanitário das aves.

Comparando-se os resultados de GMP e CA das aves suplementadas com citrato cúprico $(75 \mathrm{mg} / \mathrm{kg} \mathrm{Cu}$ ) aos 42 dias no presente estudo $(2,395 \mathrm{~kg}$ e 1,853 , respectivamente) com os resultados obtidos por Pesti \& Bakali (1996) com o mesmo tratamento $(2,31 \mathrm{~kg}$ e 1,98, respectivamente), pode-se constatar que os valores foram semelhantes em ambos os estudos. Porém, houve diferença nos resultados de GMP e CA das aves submetidas ao tratamento controle do presente estudo $(2,384 \mathrm{~kg}$ e 1,853 , respectivamente) com os resultados do trabalho dos 
autores citados anteriormente (2,15 $\mathrm{kg}$ e 2,05, respectivamente). As aves controle do presente estudo, mesmo sendo alimentadas com uma dieta basal sem suplementação de qualquer promotor de crescimento, alcançaram um PVM aos 42 dias de $2,427 \mathrm{~kg}$, o que é excelente para machos da linhagem utilizada. A partir dessas observações, pode-se constatar que a ausência de resultados positivos da ação do $\mathrm{Cu}$ na promoção de crescimento no presente estudo foi, em grande parte, devido aos altos valores de desempenho alcançados pelas aves submetidas ao tratamento controle, o que pode estar relacionado com as condições higiênico/sanitárias das instalações na condução do experimento.

Evidências confirmam que há progressivos aumentos no ganho de peso e eficiência alimentar quando o $\mathrm{Cu}$ é utilizado na dieta de frangos de corte em ensaios sucessivos. Johnson et al. (1985) testaram o efeito de $125 \mathrm{mg} \mathrm{Cu} / \mathrm{kg}$ (sulfato cúprico) na dieta de frangos de corte sobre o desempenho e a concentração deste mineral na cama e seus efeitos sobre a microflora em quatro ensaios sucessivos ao longo de 12 meses sem trocar a cama utilizada. Os autores observaram que não houve diferença significativa na taxa de crescimento e eficiência alimentar das aves nos ensaios 1 e 2, porém no ensaio 3 houve uma melhora no crescimento de aproximadamente $3 \%$ e no ensaio 4 uma melhora no ganho de peso e na conversão alimentar de aproximadamente $2 \%$. As concentrações de Cu na cama das aves suplementadas com tal mineral aumentaram significativamente para mais de $600 \mathrm{mg} / \mathrm{kg}$ no último ensaio; a concentração de fungos na cama das aves suplementadas diminuiu progressivamente com a repetição dos ensaios, porém a contagem bacteriana na cama não foi afetada significativamente pela suplementação com $\mathrm{Cu}$. Segundo os autores, a ausência de resposta dos 
frangos à suplementação de sulfato cúprico nos dois primeiros ensaios de uma série de quatro sugere que a melhora no desempenho nos ensaios 3 e 4 foram devido a outros fatores nutricionais ou ambientais e não à atividade antimicrobiana do Cu da dieta. É provável que as respostas de crescimento nos últimos ensaios do estudo estejam relacionadas com as alterações graduais na condição da cama devido ao aumento da concentração do Cu na mesma e à simultânea redução na concentração de fungos. Maiores estudos ainda são necessários para comprovar essa hipótese.

Com base nestas evidências, pode-se concluir que a realização de apenas um ensaio utilizando cama nova e em ambiente controlado para testar o efeito promotor de crescimento do $\mathrm{Cu}$, não seja suficiente para a obtenção de resultados de melhora de desempenho das aves suplementadas. Como o presente experimento constituiu-se de um único ensaio, sugere-se que haja mais repetições do estudo, visto que o estudo do Pesti \& Bakalli (1996) compreendeu um total de sete ensaios, para garantir uma comprovação mais segura da ação promotora de crescimento do Cu nas dietas de frangos de corte.

Um dos objetivos do presente estudo foi observar a ação promotora de crescimento do citrato cúprico em diferentes fases da criação (1-21 dias, 22-42 dias e 1-42 dias), pois com os resultados obtidos por Pesti \& Bakalli (1996), verificou-se que houve diferença estatística entre as médias de GMP e CA no período experimental total (42 dias), não ocorrendo o mesmo no período de 1 a 21 dias. Esses resultados não estão de acordo com os observados por alguns autores que estudaram a ação dos agentes antimicrobianos em diferentes fases da criação. 
Wisman et al. (1954) concluíram que o efeito de agentes antimicrobianos como promotores de crescimento diminui com a idade das aves e Heuser \& Norris (1952) e Fernandez et al. (1973) verificaram que o maior estímulo no crescimento de aves alimentadas com rações contendo antibióticos ocorre durante as quatro primeiras semanas de idade, desaparecendo as diferenças nos ganhos de peso após essa idade. Além disso, Marusich et al. (1973) observaram que nas fases iniciais do crescimento de pintos de corte, a adição de agentes antimicrobianos na ração resultou em melhora significativa no ganho de peso e conversão alimentar, mas nas duas últimas semanas (seis a oito) não trouxe efeito significativo no desempenho das aves.

Zuanon (1995) observou que aves recebendo o antibiótico avoparcina apresentaram melhores peso, ganho de peso e conversão alimentar $(P<0,05)$, quando comparadas com aquelas que receberam a ração testemunha até o 21 dias de idade, e ao final do período experimental não houve diferença significativa entre os tratamentos.

Esses resultados não puderam ser confirmados no presente estudo, pois não houve diferença estatística entre as suplementações de citrato cúprico nas diferentes fases testadas sobre as variáveis PVM, GMP, CONS e CA. 


\subsection{Mortalidade (MORT):}

As análises de variância para esta variável nos períodos de 1 a 21 dias, de 22 a 42 dias e de 1 a 42 dias, encontram-se nos Apêndices 14, 15 e 16.

A Tabela 7 apresenta os resultados das médias de MORT de frangos de corte submetidos à suplementação de citrato cúprico na dieta em diferentes fases e de sulfato cúprico no periodo total, analisados no período de 1 a 21 dias, de 22 a 42 dias e de 1 a 42 dias. Os dados foram transformados por arc sen $\sqrt{\% / 100}$.

Tabela 7. Efeito dos tratamentos na MORT das aves testados nos períodos de 1 a 21 dias, de 22 a 42 dias e de 1 a 42 dias da criação'.

\begin{tabular}{cccc}
\hline \multicolumn{4}{c}{ MORTALIDADE (\%) } \\
\hline Tratamentos & 1 a 21 dias & 22 a 42 dias & 1 a 42 dias \\
\hline Controle & 1,3 & 1,6 & 2,9 \\
Citrato $1-21$ & 0,0 & 0,8 & 0,8 \\
Citrato $22-42$ & 0,4 & 0,4 & 0,8 \\
Citrato $1-42$ & 0,4 & 0,8 & 1,2 \\
Sulfato & 0,8 & 1,7 & 2,5 \\
\hline \multicolumn{5}{c}{$\mathrm{CV}^{3}$} & 1,60 & 2,35 & 2,71 \\
\hline 1. Dados transformados por arc sen $\sqrt{\% / 100}$. \\
2. Contrastes: $D B$ vs. Citrato $(P=0,24) ; D B$ vs. Sulfato $(P=0,99)$; Citrato vs. Sulfato $(P=0,34)$. \\
3. Contrastes: $D B$ vs. Citrato $(P=0,07) ; D B$ vs. Sulfato $(P=0,74) ;$ Citrato vs. Sulfato $(P=0,15)$.
\end{tabular}

Não houve diferença estatística significativa entre as médias de MORT dos tratamentos nos diferentes periodos testadas através do teste de média Tukey, porém houve efeito significativo do contraste $D B$ vs. citrato $(P=0,07)$ no período total da criação. As aves que 
não receberam suplementação de $\mathrm{Cu}$ na dieta apresentaram uma maior MORT do que as suplementadas com citrato.

Esses resultados não estão de acordo com os encontrados por Ewing et al. (1997) que não observaram diferenças significativas na mortalidade entre as aves suplementadas com fontes de $\mathrm{Cu}$ e o grupo controle $(P>0,05)$. Mesmo havendo diferença significativa $(P<0,10)$ entre a MORT das aves suplementadas com citrato $e$ as aves controle no presente estudo, a taxa de mortalidade durante todo o experimento foi de $1,66 \%$, o que pode ser considerado um bom índice, tendo como causa principal a morte súbita. Não houve problemas sanitários durante o período experimental, as aves apresentaram um aspecto clínico favorável e a incidência de aves "refugos" foi muito baixa. Essas evidências comprovam o ótimo estado higiênico das instalações experimentais, o que pode ter influenciado nos resultados de desempenho das aves no período experimental.

\subsection{Resíduos de Cu na cama:}

A análise de variância para RES encontra-se no Apêndice 17. Houve efeito dos tratamentos sobre os resíduos de $\mathrm{Cu}$ na cama $(P<0,01)$.

A Tabela 8 apresenta os resultados das análises de resíduos de Cu na cama de frangos de corte submetidos à suplementação de citrato cúprico na dieta em diferentes fases e de sulfato cúprico no periodo total. 
Tabela 8. Efeito dos tratamentos nos resíduos de Cu na cama das aves aos 42 dias da criação.

\begin{tabular}{cc}
\hline Tratamentos & $\begin{array}{c}\text { Resíduos de Cu na cama } \\
\text { (ppm) }\end{array}$ \\
\hline Controle & $43,17^{\mathrm{c}}$ \\
Citrato 1-21 & $54,67^{\mathrm{c}}$ \\
Citrato 22-42 & $97,67^{\mathrm{b}}$ \\
Citrato 1-42 & $115,17^{\mathrm{b}}$ \\
Sulfato & $197,17^{\mathrm{a}}$ \\
\hline CV (\%) & 21,0 \\
\hline
\end{tabular}

Valores seguidos de letras diferentes, são estatisticamente diferentes pelo Teste de Tukey $(P<0,01)$.

Houve diferença estatística significativa entre as médias de resíduos de $\mathrm{Cu}$ na cama dos frangos submetidos aos diferentes tratamentos $(P<0,01)$. Os animais apresentaram durante $\circ$ período experimental uma média de RES de 101,567 $\pm 21,32$ ppm, sendo o menor valor igual a 33 ppm e o maior 230 ppm. As amostras de casca de arroz coletadas antes do alojamento das aves apresentaram 23 e 24 ppm de $\mathrm{Cu}$.

Os resíduos de $\mathrm{Cu}$ dos tratamentos controle e citrato 1-21 foram estatisticamente semelhantes $(43,17$ e $54,67 \mathrm{ppm}$, respectivamente). O mesmo ocorreu com os tratamentos citrato 22-42 e citrato 1-42 (97,67 e 115,17 ppm, respectivamente). Com a utilização de sulfato cúprico na ração foram observados os maiores níveis de resíduos de $\mathrm{Cu}(197,17 \mathrm{ppm})$ que diferiram estatisticamente dos tratamentos anteriores $(P<0,01)$. Com a utilização de citrato cúprico no período total ou em um dos períodos testados (1 a 21 dias ou 22 a 42 dias), os níveis de Cu na cama foram significativamente menores do que com o uso de sulfato cúprico. 
Esses resultados estão de acordo com os encontrados por Pesti e Bakalli (1996) que observaram que com o uso do citrato cúprico na dieta de frangos de corte por um período de 42 dias, os resíduos de $\mathrm{Cu}$ na cama foram significativamente menores do que com o uso de sulfato cúprico, devido aos menores níveis de citrato cúprico adicionados na ração.

Kunkle et al. (1981) analisando os resíduos de $\mathrm{Cu}$ em cama de frangos reutilizadas em cinco ou mais lotes, concluíram que os niveis de $\mathrm{Cu}$ na cama foram de 1 a 5 vezes maiores do que os adicionados na dieta. Houve uma resposta linear do nível de Cu na cama ao nível de $\mathrm{Cu}$ adicionado na dieta e tal relação indicou que o Cu da dieta foi 3,25 vezes concentrado na cama.

Vest \& Dyer (1993) observaram que os fatores que afetam a composição mineral da cama de frangos incluem a densidade de aves alojadas, a concentração de nutrientes da ração, o tipo e a quantidade de substrato (cama), o tempo de uso (reutilização) e outros fatores de manejo.

Smith et al. (1992) observaram que nenhum problema sério de toxicidade com minerais foi detectado nas forragens de pastos fertilizados com cama de frango. O aumento de níveis de $\mathrm{Cu}$ nas forragens fertilizadas com cama pode até ser desejável, visto que a maioria dos pastos parecem ser deficientes neste mineral. Além disso, o aumento de $\mathrm{Cu}$ pode ser compensado pelo aumento dos níveis de molibdênio (Mo) nos pastos fertilizados com cama de frango, pois o Mo liga-se ao $\mathrm{Cu}$ diminuindo sua disponibilidade aos animais que se alimentarem com a forragem destes pastos. Todavia, o uso da cama de frangos na alimentação de ovinos deve ser limitada, pois essa espécie é 
muito sensivel ao $\mathrm{Cu}$, e, embora o nivel de Mo também seja muito alto, não é suficiente para neutralizar a quantidade de Cu presente na cama.

Os niveis máximos de Cu toleráveis para bovinos e ovinos são respectivamente 100 e 25 ppm (NRC, 1980). Em vista disso, faz-se necessário um controle do uso do $\mathrm{Cu}$ na dieta como promotor de crescimento de frangos de corte, principalmente se for adotada a reutilização da cama em vários lotes. $\mathrm{O}$ acúmulo de resíduos de $\mathrm{Cu}$ no solo e nas forragens fertilizadas pode trazer sérios prejuízos ao meio ambiente. Além do que, a suplementação de cama de frango na dieta de ruminantes como fonte protéica, pode causar graves problemas de intoxicação, principalmente aos ovinos (Davis, 1974; Webb \& Fontenot, 1975; Ryssen et al., 1977; Miller \& Nelson, 1978; Westing et al., 1985; Banton et al., 1987 e Canton et al., 1994). 


\section{CONCLUSÕES}

De acordo com as condições em que este trabalho foi realizado, pode-se concluir que:

1) O Cu nas formas citrato cúprico anidro e sulfato cúprico pentahidratado não apresentou eficiência como promotor de crescimento para frangos de corte, contrariando uma série de trabalhos da literatura.

2) Apesar do CONS das aves que receberam citrato na dieta em todas as fases testadas ter sido levemente maior do que daquelas que receberam sulfato, e a CA das aves que receberam citrato apenas no periodo de 2242 dias ter sido pior do que daquelas que receberam sulfato, esses resultados não evidenciam diferenças importantes entre a ação do citrato e do sulfato como promotores de crescimento.

3) Não foram observadas variações nas respostas do citrato cúprico sobre o desempenho de frangos de corte nos diferentes períodos testados (1-42 dias, 1-21 dias e 22-42 dias), com exceção da pior CA no período de 22 a 42 dias da criação. 
4) Os cuidados com a limpeza e desinfecção do aviário e equipamentos antes da instalação do experimento e a baixa taxa de mortalidade total e ocorrência de aves "refugos" durante o período experimental (aproximadamente $1,66 \%$ ) confirmam o baixo desafio microbiano nas instalações, o que pode estar relacionado com o ótimo desempenho das aves controle e a ausência de efeito promotor de crescimento das fontes de Cu utilizadas.

5) A impossibilidade de se detectar diferenças nos resultados entre o controle e os demais tratamentos referentes às variáveis de desempenho sugere a necessidade da repetição do presente estudo em ensaios sucessivos nas mesmas instalações, a fim de se criar condições propícias para a ação do $\mathrm{Cu}$ como promotor de crescimento e confirmar seu mecanismo de ação.

6) Os resultados de resíduos de Cu na cama de frangos suplementados com citrato e sulfato cúprico estão de acordo com a literatura, confirmando o acúmulo de altas concentrações deste mineral na cama com o uso de fontes de $\mathrm{Cu}$ na dieta. Houve diferença estatística significativa $(P<0,01)$ entre os resíduos de $\mathrm{Cu}$ quando utilizado citrato, sulfato cúprico ou dieta controle.

7) De acordo com os resultados obtidos no presente experimento, faz-se necessário maiores estudos para avaliar em que condições o $\mathrm{Cu}$ realmente possui ação promotora de crescimento para frangos de corte, devido principalmente ao seu acúmulo na cama representar um fator de risco ao ambiente. 


\section{REFERÊNCIAS BIBLIOGRÁFICAS}

AGROCERES ROSS MELHORAMENTO GENÉTICO DE AVES S.A Manual de manejo frango de corte Agross. Rio Claro, 1997. 56p.

ANDRIGUETO, J. M.; PERLY, L.; MINARD, I. Nutrição Animal. 4. ed. São Paulo: Nobel, 1990. v.1. 395 p.

ANJUM, A D.; ANJUM, M. S.; RIZVI, F. et al. Pathological features of induced copper sulphate poisoning in broiler chicks. Pakistan Veterinary Journal. v.12, n.1, p.21-24, 1992. /Resumo em CAB Abstracts on CD-ROM, 1992/

AOYAGI, S.; BAKER, D. H. Nutritional Evaluation of copper-lysine and zinc-lysine complexes for chicks. Poultry Science, v.72, p.165-171, 1993.

AOYAGI, S.; BAKER, D. H. Effect of high copper dosing on hemicellulose digestibility in cecectomized cockerels. Poultry Science, v.74, n.208211, 1995. 
BAKER, D. H.; ODLE, J.; FUNK, M. A. et al. Bioavailability of copper in cupric oxide, cuprous oxide, and in a copper-lysine complex. Poultry Science, v.70, p. 177-179, 1991.

BANTON, M. I.; NICHOLSON, S. S.; JOWET, P. L. H. et al. Copper toxicosis in cattle fed chicken litter. Journal of the American Veterinary Medical Association, v. 191, n.7, p.827-828, 1987. /Resumo em CAB abstracts on CD-ROM, 1990-87/

BUNCH, R. J.; SPEER, V. C.; HAYS, V. W. et al. Effects of copper sulfate, copper oxide and chlortetracycline on baby pig performance. Journal of Animal Science, v.20, p. 723-726, n.1, 1961.

CANTON, J. G. C.; MOGUEL, O. Y.; ROJAS, R. et al. Estimation of damage induced by copper in poultry litter used in feeding sheep. Tecnica Pecuaria en Mexico, v. 32, n. 2, p. 82-89, 1994 . /Resumo em CAB abstracts on CD-ROM, 1993-94/

CROMWELL, G. L. Agents antimicrobial. In: MILLER, E. R.; ULREY, D. E.; LEWIS, A. J. Swine nutrition. Stoneham: ButterworthHeinemann, 1991. p.297-314.

CROMWELL, G. L.; STAHLY, T. S.; MONEGUE, H. J. Effects of source and level of copper on performance and liver copper stores in wealing pigs. Journal of Animal Science, v.67, p.2996-3002, 1989. 
CUNHA, T. J. Swine feeding and nutrition. New York: Academic Press, 1977. 352p.

DAVIS, G. K. High level copper feeding of swine and poultry and the ecology. Federation Proceedings, v.33, n.5, p.1194-1196, 1974. /Resumo em CAB Abstracts on CD-ROM, 1972-75/

DIERICK, N. A.; VERVAEKE, I. J.; DECUYPERE, J. A. et al. Influence of the gut flora and some growth-promoting feed additives on nitrogen metabolism in pigs. 2. Studies in vivo. Livestock Production Science, v.14, n.2, p.177-193, 1986.

DOVE, C. R. The effect of copper level on nutrient utilization of weanling pigs. Journal of Animal Science, v.73, n.166-171, 1995.

EWING, H. P.; PESTI, G. M.; BAKALLI, R. I. et al. Cupric sulfate pentahydrate, cupric citrate and copper oxychloride as broiler supplements. Poultry Science, v.76, n.1, p. 59, 1997.

FERNANDEZ, R.; LUCAS, E.; McGINNIS, J. Influence of diet composition on chick growth response to different antibiotics, feed aditives and combination of the aditives. Poultry Science, v. 52, p. 2299-2305, 1973. 
FISHER, C.; LAURSEN-JONES, A P.; HILL, K. J. et al. The effect of copper sulphate on performance and the estructure of the gizzard in broilers. British Poultry Science, v.14, n.1, p.55-68, 1973. /Resumo em CAB Abstracts on CD-ROM, 1972-75/

GUENTHNER, E.; CARLSON, C. W.; EMERICK, R. J. Copper salts for growth stimulation and alleviation of aortic rupture losses in turkeys. Poultry Science, v.57, p.1313-1324, 1978.

HARADA, Y.; HAGA, K.; OSADA, T. et al. Quality of compost produced from animal wastes. Japan Agricultural Research Quarterly, v.26, n.4, p.238-246, 1993. /Resumo em CAB Abstracts on CD-ROM, 1995/

HARPER, H. A; RODWELL. V. W.; MAYNES, P. A Manual de química fisiológica. 5.ed. São Paulo: Atheneu, 1982. 736p.

HAWBAKER, J. A ; SPEER, V. C.; JONES, J. D. et al. Effect of copper sulfate and antibiotics on growth rate, feed conversion and fecal flora of growing pigs. Journal of Animal Science, v.18, n.3, p. 1505-1506, 1959.

HEUSER, G. F.; NORRIS, L. C. Some results of feeding antibiotics to chickens. Poultry Science, v. 31, p. 857-862, 1952. 
HILL, D. C.; BRANION, H. D.; SLINGER, S. J. et al. Influence of environment on the growth response of chicks to penicillin. Poultry Science, v.32, n. 462-475, 1953.

HODA, A. A.; MAHA, M. H. Potency of copper as growth promoter in broiler chickens. Veterinary Medical Journal, v.43, p.77-85, 1995.

JENSEN, L. S.; MAURICE, D. V. Effect of high dietary copper on the ceca of chicks. Poultry Science, v.57, n.1, p. 166-170, 1978.

JENSEN, L. S.; DUNN, P. A ; DOBSON, K. N. Induction of oral lesions in broiler chicks by supplementing the diet with copper. Avian Diseases, v.35, n.4, p.969-973, 1991. /Resumo em CAB abstracts on CDROM, 1990-91/

JOHNSON, E. L.; NICHOLSON, J. L.; DOERR, J. A Effect of dietary copper on litter microbial population and broiler performance. British Poultry Science, v.26, p.171-177, 1985.

KINGERY, W. L.; WOOD, C. W.; DELANEY, D. P. et al. Implications of long-term land application of poultry litter on tall fescues pastures. Journal of Production Agriculture, v.6, n.3, p.390-395, 1993. /Resumo em CAB Abstracts on CD-ROM, 1995/ 
KINGERY, W. L.; WOOD, C. W.; DELANEY, D. P. et al. Impact of longterm land application of broiler litter on environmentally related soil properties. Journal of Environmental Quality, v.23, n.1, p.139-147, 1994. /Resumo em FSTA on CD-ROM, 1969-95/

KLASING, K. C.; LAURIN, D. E.; PENG et al. Immunologically mediated growth depression in chicks: influence of feed intake, corticosterone and interleukin-1. Journal of Nutrition, v. 117, p.1629-1637, 1987.

KOLB, E. Microfactores en Nutricion Animal. Zaragoza: Acribia, 1972. $270 p$.

KUNKLE, W. E.; CARR, L. E.; CARTER, T. A. et al. Effect of flock and floor type on the levels of nutrients and heavy metals in broiler litter. Poultry Science, v.60, n.6, p.1160-1164, 1981.

LEDOUX, D. R.; AMMERMAN, C. B.; MILES, R. D. Biological availability of copper sources for broiler chicks. Poultry Science, v.66, p.24, 1987.

LUO, X. G.; DOVE, C. R. Effect of dietary copper and fat on nutrient utilization, digestive enzyme activities, and tissue mineral levels in weanling pigs. Journal of Animal Science, v.74, n.1888-1896, 1996.

MARUSICH, W. L.; OGRINZ, E. E.; BROWN, P. R. et al. Comparative efficacy of intermittent and continuous feeding of four antibiotics at low levels to broilers. Poultry Science, v. 52, p. 1774-1779, 1973. 
MAYNARD, L. A.; LOOSLI, J. K.; HINTZ, H. F. et al. Nutrição animal. 3. ed. Rio de Janeiro: Freitas Bastos, 1984. 726p.

McDOWELL, L. R. Minerals in animal and human nutrition. New York: Academic Press, 1992. 542 p.

MENTEN, J. F. M. Eficácia, efeito sinérgico e modo de ação de agentes antimicrobianos como promotores do crescimento de suinos. Piracicaba, 1995. 106p. Tese (Livre-Docência) - Escola Superior de Agricultura "Luiz de Queiroz", Universidade de São Paulo.

MERCK \& Co. The Merck index. 11 ed. Rahway, 1989. 412p.

MERCK \& Co. The Merck veterinary manual: a handbook of diagnosis, therapy and disease prevention and control for the veterinarian. $7 \mathrm{ed}$. Rahway, 1991. 1832p.

MERTZ, W. Trace elements in human and animal nutrition. 5. ed. San Diego: Academic Press, 1987. v.1, 480p.

MILLER, S.; NELSON, H. A Copper poisoning in sheep grazing pastures fertilized with chicken litter. Journal of the American Veterinary Medical Association, v.173, n.12, p.1587-1589, 1978. /Resumo em CAB Abstracts on CD-ROM, 1976-78/

NATIONAL RESEARCH COUNCIL. Mineral tolerance of domestic animals. Washington: National Academy of Sciences, 1980. 577p. 
NATIONAL RESEARCH COUNCIL. Nutrient Requirements of Poultry. 9 ed. Washington: National Academy Press, 1994. 155p.

NORVELL, M. J.; CALVERT, C. C.; THOMAS, M. C. et al. The effects of copper sulfate suplementation in broiler chicken diets on growth and select toxicological parameters. Poultry Science, v.53, n.2, p.1641, 1974. IApresentado ao Annual Meeting of the Poultry Section of the Southern Association of Agricultural Scientists, Atlanta, 1974 Abstracts/

PESTI, G. M.; BAKALLI, R. I. Studies on the feeding of cupric sulfate pentahidrate and cupric citrate to broiler chickens. Poultry Science, v.75, p.1086-1091, 1996.

POUPOULIS, C.; JENSEN, L. S. Effect of high dietary copper on gizzard integrity of the chick. Poultry Science, v.55, p.113-121, 1976.

RADECKI, S. V.; KU, P. K.; BENNINK, M. R. et al. Effect of dietary copper on intestinal mucosa enzyme activity, morphology, and turnover rates in weanling pigs. Journal of Animal Science, v.70, p.1424-1431, 1992.

ROBBINS, K. R.; BAKER, D. H. Effect of high level copper feeding on the sulfur amino acid need of chicks fed corn-soybean meal and purified crystalline amino acid diets. Poultry Science, v.59. p.1099-1108, 1980. 
ROSTAGNO, H. S.; SILVA, D. J.; COSTA, P. M. A. et al. Composição de alimentos e exigências nutricionais de aves e suínos (tabelas brasileiras). Viçosa: UFV, Impr. Univ., 1994. 59p.

ROURA, E.; HOMEDES, J.; KLASING, K. C. Prevention of immunologic stress contributes to the growth-permitting ability of dietary antibiotics in chicks. Journal of Nutrition, v. 122, p.2383-2390, 1992.

RUTZ, F. Absorção de minerais e vitaminas. In: FUNDAÇÃO APINCO DE CIÊNCIA E TECNOLOGIA AVÍCOLAS. Fisiologia da digestão e absorção das aves. Campinas, 1994. p. 83-98.

RYSSEN, J. B. J. van; CHANNON, P.; STIELAU, W. J. Minerals and nitrogen in poultry manure. South African Journal of Animal Science, v.7, n.3, p.195-199, 1977. /Resumo em CAB Abstracts on CD-ROM, 1976-78/

SCOTT, M. L.; NESHEIM, M. C.; YOUNG, R. J. Nutrition of the chicken. New York: M. L. Scott e Associates, 1969. 561p.

SMITH, S. C.; BRITTON, J. G.; ENIS, K. C. et al. Mineral levels of broiler litter need close monitoring. Feedstuffs, v.64, n.43, p. 14-16, 1992.

SMITH, S. C.; BRITTON, J. G.; ENIS, J. D. et al. Mineral levels of broiler house litter and forages and soils fertilized with litter. Animal Science Research Report, n. P-933, p.153-159, 1993. /Resumo em CAB Abstracts on CD-ROM, 1993-94/ 
STARCHER, B. C. Studies on the mechanism of copper absorption in the chick. Journal of Nutrition, v.97, p.321-326, 1969.

STETSENKO, I. I.; KUZNETSOV, S. G.; BATAEVA, A. P. Absorption of copper and zinc in piglets during different levels of feeding. Byulleten-Vsesoyuznogo Nauchno issledovatel'skogo Instituta Fiziologii Biokhimii i Pitaniya Sel'skoklozyaistvennykh. n. 2-78, p. 40-43, 1985. /Resumo em CAB Abstracts on CD-ROM, 1984-86/

SWENSON, M. J.; REECE, W. O.; DUKES, H. N. Dukes fisiologia dos animais domésticos. 11. ed. Rio de Janeiro: Guanabara Koogan, 1996. 856p.

TIESENHAUSEN, I. M. E. V. von Resíduos avícolas na alimentação dos ruminantes. Revista dos Criadores, v.55, n.671, p. 25-28, 1985.

UNDERWOOD, E. J. Trace elements in human and animal nutrition. 4. ed. New York: Academic Press, 1977. 545 p.

VEST, L.; DYER, J. Many factors affect broiler litter's mineral composition. Poultry Digest, Sept. 1993. p. 30-32.

VISEK, W. J. The mode of growth promotion by antibiotics. Journal of Animal Science, v.46, n.5, 1978. 
WEBB Jr., K. E.; FONTENOT, J. P. Medicinal drugs residues in broiler litter and tissues from cattle fed litter. Journal of Animal Science, v. 41, n.4, p.1212-1217, 1975.

WEsting, T. W.; FONTENOT, J. P.; McCluRE, W. $H$. et al. Characterization of mineral element profiles in animal waste and tissues from cattle fed animal waste. 1. Heifers fed broiler litter. Journal of Animal Science, v.61, n.3, p.670-681, 1985

WIDERMAN Jr, R. F.; KIRBY, Y. K.; BARTON, T. L. et al. Excess dietary copper triggers enlargement of the proventriculus in broilers. Journal of Applied Poultry Research, v.5, n.3, p.219-230, 1996.

ZHOU, W.; KORNEGAY, E. T.; LINDEMANN, M. D. et al. Stimulation of growth by intravenous injection of copper in wealing pigs. Journal of Animal Science, v.72, p.2395-2403, 1994a.

ZHOU, W.; KORNEGAY, E. T.; van LAAR, H. et al. The role of feed consumption and feed consumption and feed efficiency in copperstimulated growth. Journal of Animal Science, v. 72, p.2385-2394, 1994b.

ZUANON, J. A S. Efeito de promotores de crescimento sobre o desempenho de frangos de corte. Viçosa, 1995. 70p. Dissertação (M.S.) - Universidade Federal de Viçosa. 


\section{APÊNDICE}

Apêndice 1. Temperaturas máximas e mínimas registradas diariamente no aviário durante o período de 1 a 21 dias do experimento.

\begin{tabular}{ccc}
\hline DATA & TEMP. MÁXIMA $\left({ }^{0} \mathbf{C}\right)$ & TEMP. MíNIMA $\left({ }^{0} \mathbf{C}\right)$ \\
\hline $06 / 11 / 97$ & 29,0 & 25,0 \\
$07 / 11 / 97$ & 33,0 & 24,0 \\
$08 / 11 / 97$ & 34,0 & 24,0 \\
$09 / 11 / 97$ & 35,0 & 23,0 \\
$10 / 11 / 97$ & 37,0 & 23,0 \\
$11 / 11 / 97$ & 37,0 & 24,0 \\
$12 / 11 / 97$ & 37,0 & 24,0 \\
$13 / 11 / 97$ & 33,0 & 24,0 \\
$14 / 11 / 97$ & 33,0 & 24,0 \\
$15 / 11 / 97$ & 32,0 & 21,0 \\
$16 / 11 / 97$ & 29,0 & 22,0 \\
$17 / 11 / 97$ & 26,0 & 22,0 \\
$18 / 11 / 97$ & 29,0 & 22,0 \\
$19 / 11 / 97$ & 27,0 & 21,0 \\
$20 / 11 / 97$ & 27,0 & 21,0 \\
$21 / 11 / 97$ & 31,0 & 22,0 \\
$22 / 11 / 97$ & 33,0 & 21,0 \\
$23 / 11 / 97$ & 32,0 & 24,0 \\
$24,11 / 97$ & 33,0 & 22,5 \\
$25 / 11 / 97$ & 32,0 & 22,0 \\
$26 / 11 / 97$ & 29,0 & 23,0 \\
\hline
\end{tabular}


Apêndice 2. Temperaturas máximas e mínimas registradas diariamente no aviário durante o período de 22 a 42 dias do experimento.

\begin{tabular}{ccc}
\hline DATA & TEMP. MÁXIMA $\left({ }^{0} \mathrm{C}\right)$ & TEMP. MíNIMA ${ }^{0} \mathrm{C}$ \\
\hline $27 / 11 / 97$ & 28,0 & 24,0 \\
$28 / 11 / 97$ & 28,0 & 22,0 \\
$29 / 11 / 97$ & 27,0 & 21,0 \\
$30 / 11 / 97$ & 29,0 & 19,0 \\
$01 / 12 / 97$ & 31,5 & 22,0 \\
$02 / 12 / 97$ & 28,0 & 24,0 \\
$03 / 12 / 97$ & 29,0 & 23,0 \\
$04 / 12 / 97$ & 31,0 & 23,0 \\
$05 / 12 / 97$ & 27,0 & 22,0 \\
$06 / 12 / 97$ & 33,0 & 23,0 \\
$07 / 12 / 97$ & 33,0 & 25,0 \\
$08 / 12 / 97$ & 32,0 & 25,0 \\
$09 / 12 / 97$ & 32,0 & 22,0 \\
$10 / 12 / 97$ & 29,0 & 21,0 \\
$11 / 12 / 97$ & 33,0 & 21,0 \\
$12 / 12 / 97$ & 32,0 & 21,0 \\
$13 / 12 / 97$ & 32,0 & 22,0 \\
$14 / 12 / 97$ & 33,0 & 24,0 \\
$15 / 12 / 97$ & 32,0 & 25,0 \\
$16 / 12 / 97$ & 29,0 & 25,0 \\
$17 / 12 / 97$ & 32,0 & 21,0 \\
\hline
\end{tabular}

Apêndice 3. Análise de Variância do peso vivo médio das aves aos 21 dias de idade'.

\begin{tabular}{lccccc}
\hline Causas de Variação & G.L. & $\begin{array}{c}\text { Soma dos } \\
\text { quadrados }\end{array}$ & $\begin{array}{c}\text { Quadrado } \\
\text { médio }\end{array}$ & F & $\begin{array}{c}\text { Prob > } \\
\text { F }\end{array}$ \\
\hline Tratamentos & 4 & 0,00451913 & 0,00112978 & 3,55 & 0,0242 \\
Blocos & 5 & 0,00203630 & 0,00040726 & 1,28 & 0,3119 \\
Resíduo & 20 & 0,00637087 & 0,00031854 & & \\
\hline Total & 29 & 0,01292630 & & & \\
\hline
\end{tabular}

coeficiente de variação: 2,30 
Apêndice 4. Análise de Variância do peso vivo médio das aves aos 42 dias idade ${ }^{1}$.

\begin{tabular}{lccccc}
\hline Causas de Variação & G.L. & $\begin{array}{c}\text { Soma dos } \\
\text { quadrados }\end{array}$ & $\begin{array}{c}\text { Quadrado } \\
\text { médio }\end{array}$ & $\begin{array}{c}\text { F } \\
\text { Prob > } \\
\text { F }\end{array}$ \\
\hline Tratamentos & 4 & 0,00259820 & 0,000649555 & 0,34 & 0,8470 \\
Blocos & 5 & 0,01143387 & 0,00228677 & 1,20 & 0,3445 \\
Resíduo & 20 & 0,03808980 & 0,00190449 & & \\
\hline Total & 29 & 0,05212187 & & & \\
\hline
\end{tabular}

'coeficiente de variação: 1,80

Apêndice 5. Análise de Variância do ganho médio em peso das aves no período de 1 a 21 dias da criação'.

\begin{tabular}{lccccc}
\hline Causas de Variação & G.L. & $\begin{array}{c}\text { Soma dos } \\
\text { quadrados }\end{array}$ & $\begin{array}{c}\text { Quadrado } \\
\text { médio }\end{array}$ & F & $\begin{array}{c}\text { Prob > } \\
\text { F }\end{array}$ \\
\hline Tratamentos & 4 & 0,00454153 & 0,00113538 & 3,51 & 0,0250 \\
Blocos & 5 & 0,00228200 & 0,00045640 & 1,41 & 0,2624 \\
Residuo & 20 & 0,00646167 & 0,00032308 & & \\
\hline Total & 29 & 0,01328520 & & & \\
\hline
\end{tabular}

coeficiente de variação: 2,45

Apêndice 6. Análise de Variância do ganho médio em peso das aves no período de 22 a 42 dias da criação'.

\begin{tabular}{lccccc}
\hline Causas de Variação & G.L. & $\begin{array}{c}\text { Soma dos } \\
\text { quadrados }\end{array}$ & $\begin{array}{c}\text { Quadrado } \\
\text { médio }\end{array}$ & F & $\begin{array}{c}\text { Prob > } \\
\text { F }\end{array}$ \\
\hline Tratamentos & 4 & 0,00587480 & 0,00146870 & 1,30 & 0,3050 \\
Blocos & 5 & 0,00553737 & 0,00110747 & 0,98 & 0,4553 \\
Resíduo & 20 & 0,02265480 & 0,00113274 & & \\
\hline Total & 29 & 0,03406697 & & & \\
\hline
\end{tabular}

coeficiente de variação: 2,03 
Apêndice 7. Análise de Variância do ganho médio em peso das aves no período de 1 a 42 dias da criação ${ }^{1}$.

\begin{tabular}{lccccc}
\hline Causas de Variação & G.L. & $\begin{array}{c}\text { Soma dos } \\
\text { quadrados }\end{array}$ & $\begin{array}{c}\text { Quadrado } \\
\text { médio }\end{array}$ & $\begin{array}{c}\text { Prob > } \\
\text { F }\end{array}$ \\
\hline Tratamentos & 4 & 0,00255020 & 0,00063755 & 0,33 & 0,8531 \\
Blocos & 5 & 0,01193257 & 0,00238651 & 1,24 & 0,3264 \\
Residuo & 20 & 0,03840060 & 0,00192003 & & \\
\hline Total & 29 & 0,05288337 & & & \\
\hline
\end{tabular}

Apêndice 8. Análise de Variância do consumo alimentar médio das aves no período de 1 a 21 dias da criação ${ }^{1}$.

\begin{tabular}{lccccc}
\hline Causas de Variação & G.L. & $\begin{array}{c}\text { Soma dos } \\
\text { quadrados }\end{array}$ & $\begin{array}{c}\text { Quadrado } \\
\text { médio }\end{array}$ & $\begin{array}{c}\text { Frob > } \\
\text { F }\end{array}$ \\
\hline Tratamentos & 4 & 0,00763413 & 0,00190853 & 3,61 & 0,0227 \\
Blocos & 5 & 0,00279947 & 0,00055989 & 1,06 & 0,4119 \\
Resíduo & 20 & 0,01057587 & 0,00052879 & & \\
\hline Total & 29 & 0,02100947 & & & \\
\hline
\end{tabular}

Apêndice 9. Análise de Variância do consumo alimentar médio das aves no período de 22 a 42 dias da criação ${ }^{1}$.

\begin{tabular}{lccccc}
\hline Causas de Variação & G.L. & $\begin{array}{c}\text { Soma dos } \\
\text { quadrados }\end{array}$ & $\begin{array}{c}\text { Quadrado } \\
\text { médio }\end{array}$ & $\begin{array}{c}\text { F } \\
\text { Prob > } \\
\text { F }\end{array}$ \\
\hline Tratamentos & 4 & 0,02329220 & 0,00582305 & 1,38 & 0,2767 \\
Blocos & 5 & 0,02078427 & 0,00415685 & 0,98 & 0,4515 \\
Resíduo & 20 & 0,08443740 & 0,00422187 & & \\
\hline Total & 29 & 0,12851387 & & & \\
\hline
\end{tabular}

coeficiente de variação: 1,98 
Apêndice 10. Análise de Variância do consumo alimentar médio das aves no período de 1 a 42 dias da criação ${ }^{1}$.

\begin{tabular}{|c|c|c|c|c|c|}
\hline Causas de Variação & G.L. & $\begin{array}{l}\text { Soma dos } \\
\text { quadrados }\end{array}$ & $\begin{array}{l}\text { Quadrado } \\
\text { médio }\end{array}$ & $\mathbf{F}$ & $\begin{array}{c}\text { Prob }> \\
F\end{array}$ \\
\hline $\begin{array}{l}\text { Tratamentos } \\
\text { Blocos } \\
\text { Resíduo }\end{array}$ & $\begin{array}{c}4 \\
5 \\
20\end{array}$ & $\begin{array}{l}0,02531587 \\
0,03200787 \\
0,07939413 \\
\end{array}$ & $\begin{array}{l}0,00632897 \\
0,00640157 \\
0,00396971\end{array}$ & $\begin{array}{l}1,59 \\
1,61\end{array}$ & $\begin{array}{l}0,2147 \\
0,2024\end{array}$ \\
\hline Total & 29 & 0,13671787 & & & \\
\hline
\end{tabular}

coeficiente de variação: 1,42

Apêndice 11. Análise de Variância da conversão alimentar das aves no período de 1 a 21 dias da criação ${ }^{1}$.

\begin{tabular}{lccccc}
\hline Causas de Variação & G.L. & $\begin{array}{c}\text { Soma dos } \\
\text { quadrados }\end{array}$ & $\begin{array}{c}\text { Quadrado } \\
\text { médio }\end{array}$ & $\begin{array}{c}\text { Prob > } \\
\text { F }\end{array}$ \\
\hline Tratamentos & 4 & 0,01328287 & 0,00332072 & 1,05 & 0,4085 \\
Blocos & 5 & 0,01120547 & 0,00224109 & 0,71 & 0,6257 \\
Resíduo & 20 & 0,06349353 & 0,00317468 & & \\
\hline Total & 29 & 0,08798187 & & & \\
\hline
\end{tabular}

coeficiente de variação: 3,60

Apêndice 12. Análise de Variância da conversão alimentar das aves no período de 22 a 42 dias da criação'.

\begin{tabular}{lccccc}
\hline Causas de Variação & G.L. & $\begin{array}{c}\text { Soma dos } \\
\text { quadrados }\end{array}$ & $\begin{array}{c}\text { Quadrado } \\
\text { médio }\end{array}$ & $\begin{array}{c}\text { Prob > } \\
\text { F }\end{array}$ \\
\hline Tratamentos & 4 & 0,01327980 & 0,00331995 & 4,72 & 0,0076 \\
Blocos & 5 & 0,00843777 & 0,00168755 & 2,40 & 0,0734 \\
Resíduo & 20 & 0,01405340 & 0,00070267 & & \\
\hline Total & 29 & 0,03577097 & & & \\
\hline
\end{tabular}

coeficiente de variação: 1,33 
Apêndice 13. Análise de Variância da conversão alimentar das aves no periodo de 1 a 42 dias da criação'.

\begin{tabular}{lccccc}
\hline Causas de Variação & G.L. & $\begin{array}{c}\text { Soma dos } \\
\text { quadrados }\end{array}$ & $\begin{array}{c}\text { Quadrado } \\
\text { médio }\end{array}$ & F & $\begin{array}{c}\text { Prob > } \\
\text { F }\end{array}$ \\
\hline Tratamentos & 4 & 0,00156633 & 0,00039158 & 0,56 & 0,6955 \\
Blocos & 5 & 0,00386480 & 0,00077296 & 1,10 & 0,3903 \\
Resíduo & 20 & 0,01402887 & 0,00070144 & & \\
\hline Total & 29 & 0,01946000 & & & \\
\hline
\end{tabular}

coeficiente de variação: 1,43

Apêndice 14. Análise de Variância da mortalidade das aves no período de 1 a 21 dias da criação ${ }^{1,2}$.

\begin{tabular}{lccccc}
\hline Causas de Variação & G.L. & $\begin{array}{c}\text { Soma dos } \\
\text { quadrados }\end{array}$ & $\begin{array}{c}\text { Quadrado } \\
\text { médio }\end{array}$ & $\begin{array}{c}\text { F } \\
\text { Prob > } \\
\text { F }\end{array}$ \\
\hline Tratamentos & 4 & 0,00054296 & 0,00013574 & 0,84 & 0,5134 \\
Blocos & 5 & 0,00085603 & 0,00017121 & 1,07 & 0,4087 \\
Resíduo & 20 & 0,00321458 & 0,00016073 & & \\
\hline Total & 29 & 0,00461357 & & & \\
\hline Coeficiente de variação: 1,60 & \\
2. Dados transformados por arc sen $\sqrt{\% / 100}$ &
\end{tabular}

Apêndice 15. Análise de Variância da mortalidade das aves no período de 22 a 42 dias da criação'.

\begin{tabular}{|c|c|c|c|c|c|}
\hline Causas de Variação & G.L. & $\begin{array}{l}\text { Soma dos } \\
\text { quadrados }\end{array}$ & $\begin{array}{c}\text { Quadrado } \\
\text { médio }\end{array}$ & $\mathbf{F}$ & $\begin{array}{c}\text { Prob > } \\
\text { F } \\
\end{array}$ \\
\hline $\begin{array}{l}\text { Tratamentos } \\
\text { Blocos } \\
\text { Resíduo }\end{array}$ & $\begin{array}{c}4 \\
5 \\
20\end{array}$ & $\begin{array}{l}0,00075432 \\
0,00186468 \\
0,00703064\end{array}$ & $\begin{array}{l}0,00018858 \\
0,00037294 \\
0,00035153\end{array}$ & $\begin{array}{l}0,54 \\
1,06\end{array}$ & $\begin{array}{l}0,7106 \\
0,4109\end{array}$ \\
\hline Total & 29 & 0,00714515 & & & \\
\hline
\end{tabular}


Apêndice 16. Análise de Variância da mortalidade das aves no período de 1 a 42 dias da criação ${ }^{1,2}$.

\begin{tabular}{lccccc}
\hline Causas de Variação & G.L. & $\begin{array}{c}\text { Soma dos } \\
\text { quadrados }\end{array}$ & $\begin{array}{c}\text { Quadrado } \\
\text { médio }\end{array}$ & $\begin{array}{c}\text { Frob > } \\
\text { F }\end{array}$ \\
\hline Tratamentos & 4 & 0,00230676 & 0,00057669 & 1,21 & 0,3363 \\
Blocos & 5 & 0,00243240 & 0,00048648 & 1,02 & 0,4304 \\
Residuo & 20 & 0,00950686 & 0,00047534 & & \\
\hline Total & 29 & 0,01424602 & & & \\
\hline Coeficiente de variação: 2,72 & \multicolumn{7}{c}{ Dados transformados por arc sen $\sqrt{\% / 100}$} &
\end{tabular}

Apêndice 17. Análise de Variância dos resíduos de Cu na cama das aves no período de 1 a 42 dias da criação'.

\begin{tabular}{lccccc}
\hline $\begin{array}{c}\text { Causas de } \\
\text { Variação }\end{array}$ & G.L. & $\begin{array}{c}\text { Soma dos } \\
\text { quadrados }\end{array}$ & $\begin{array}{c}\text { Quadrado } \\
\text { médio }\end{array}$ & F & Prob > F \\
\hline Tratamentos & 4 & 89698,2000 & 22424,5500 & 49,32 & 0,0001 \\
Blocos & 5 & 4731,3667 & 946,2733 & 2,08 & 0,1104 \\
Resíduo & 20 & 9093,8000 & 454,6900 & & \\
\hline Total & 29 & 103523,3667 & & & \\
\hline
\end{tabular}

1 Coeficiente de variação: 21,0

Apêndice 18. Resíduos de $\mathrm{Cu}(\mathrm{ppm})$ na cama de frangos de corte.

\begin{tabular}{cccccc}
\hline \multicolumn{5}{c}{ TRATAMENTOS } \\
\hline Blocos & Controle & Citrato 1-21 & Citrato 22-42 & Citrato 1-42 & Sulfato \\
$\mathbf{1}$ & 53 & 69 & 109 & 133 & 218 \\
$\mathbf{2}$ & 49 & 64 & 111 & 150 & 160 \\
$\mathbf{3}$ & 48 & 61 & 77 & 70 & 152 \\
$\mathbf{4}$ & 33 & 37 & 107 & 100 & 202 \\
$\mathbf{5}$ & 35 & 38 & 63 & 100 & 230 \\
$\mathbf{6}$ & 41 & 59 & 119 & 138 & 221 \\
\hline MÉDIA & $\mathbf{4 3}$ & $\mathbf{5 5}$ & $\mathbf{9 8}$ & $\mathbf{1 1 5}$ & $\mathbf{1 9 7}$ \\
\hline
\end{tabular}


Apêndice 19. Peso vivo médio $(\mathrm{kg})$ semanal das aves.

\begin{tabular}{|c|c|c|c|c|c|c|c|c|}
\hline \multirow[b]{2}{*}{ TRATAMENTO } & \multirow[b]{2}{*}{ BLOCOS } & \multicolumn{7}{|c|}{ DIAS } \\
\hline & & 1 & 7 & 14 & 21 & 28 & 35 & 42 \\
\hline \multirow{7}{*}{ CONTROLE } & 1 & 0,044 & 0,130 & 0,374 & 0,763 & 1,292 & 1,792 & 2,386 \\
\hline & 2 & 0,043 & 0,135 & 0,390 & 0,763 & 1,258 & 1,840 & 2,448 \\
\hline & 3 & 0,044 & 0,130 & 0,368 & 0,753 & 1,240 & 1,818 & 2,338 \\
\hline & 4 & 0,043 & 0,120 & 0,388 & 0,782 & 1,282 & 1,779 & 2,431 \\
\hline & 5 & 0,043 & 0,135 & 0,385 & 0,780 & 1,287 & 1,866 & 2,484 \\
\hline & 6 & 0,042 & 0,140 & 0,410 & 0,808 & 1,303 & 1,878 & 2,475 \\
\hline & MÉDIA & 0,043 & 0,132 & 0,386 & 0,775 & 1,277 & 1,829 & 2,427 \\
\hline \multirow{7}{*}{$\begin{array}{l}\text { CITRATO } \\
\text { 1-21 DIAS }\end{array}$} & 1 & 0,044 & 0,133 & 0,388 & 0,778 & 1,288 & 1,885 & 2,443 \\
\hline & 2 & 0,044 & 0,138 & 0,390 & 0,775 & 1,255 & 1,845 & 2,379 \\
\hline & 3 & 0,044 & 0,140 & 0,398 & 0,798 & 1,305 & 1,915 & 2,444 \\
\hline & 4 & 0,044 & 0,140 & 0,400 & 0,795 & 1,308 & 1,878 & 2,423 \\
\hline & 5 & 0,043 & 0,138 & 0,408 & 0,808 & 1,320 & 1,923 & 2,483 \\
\hline & 6 & 0,042 & 0,145 & 0,415 & 0,805 & 1,300 & 1,895 & 2,485 \\
\hline & MÉDIA & 0,044 & 0,139 & 0,400 & 0,793 & 1,296 & 1,890 & 2,443 \\
\hline \multirow{7}{*}{$\begin{array}{l}\text { CITRATO } \\
\text { 22-42 DIAS }\end{array}$} & 1 & 0,043 & 0,140 & 0,403 & 0,805 & 1,313 & 1,910 & 2,458 \\
\hline & 2 & 0,043 & 0,135 & 0,395 & 0,770 & 1,274 & 1,808 & 2,377 \\
\hline & 3 & 0,044 & 0,133 & 0,375 & 0,758 & 1,265 & 1,818 & 2,388 \\
\hline & 4 & 0,043 & 0,143 & 0,403 & 0,783 & 1,280 & 1,853 & 2,405 \\
\hline & 5 & 0,043 & 0,140 & 0,403 & 0,805 & 1,313 & 1,838 & 2,480 \\
\hline & 6 & 0,042 & 0,135 & 0,390 & 0,790 & 1,285 & 1,874 & 2,415 \\
\hline & MÉDIA & 0,043 & 0,138 & 0,395 & 0,785 & 1,288 & 1,850 & 2,421 \\
\hline \multirow{7}{*}{ 1-42 DIAS } & 1 & 0,044 & 0,135 & 0,390 & 0,768 & 1,282 & 1,903 & 2,436 \\
\hline & 2 & 0,044 & 0,125 & 0,368 & 0,746 & 1,285 & 1,849 & 2,387 \\
\hline & 3 & 0,043 & 0,135 & 0,378 & 0,778 & 1,295 & 1,900 & 2,478 \\
\hline & 4 & 0,044 & 0,140 & 0,395 & 0,788 & 1,298 & 1,905 & 2,483 \\
\hline & 5 & 0,043 & 0,130 & 0,368 & 0,733 & 1,230 & 1,838 & 2,390 \\
\hline & 6 & 0,042 & 0,133 & 0,373 & 0,745 & 1,272 & 1,877 & 2,456 \\
\hline & MÉDIA & 0,043 & 0,133 & 0,379 & 0,760 & 1,277 & 1,879 & 2,438 \\
\hline \multirow{7}{*}{ SULFATO } & 1 & 0,044 & 0,133 & 0,367 & 0,749 & 1,262 & 1,803 & 2,345 \\
\hline & 2 & 0,044 & 0,138 & 0,380 & 0,762 & 1,295 & 1,869 & 2,410 \\
\hline & 3 & 0,044 & 0,133 & 0,378 & 0,770 & 1,283 & 1,888 & 2,455 \\
\hline & 4 & 0,043 & 0,130 & 0,375 & 0,768 & 1,285 & 1,908 & 2,465 \\
\hline & 5 & 0,044 & 0,130 & 0,375 & 0,750 & 1,260 & 1,855 & 2,427 \\
\hline & 6 & 0,042 & 0,138 & 0,398 & 0,795 & 1,298 & 1,915 & 2,418 \\
\hline & MÉDIA & 0,044 & 0,134 & 0,379 & 0,766 & 1,281 & 1,873 & 2,420 \\
\hline
\end{tabular}


Apêndice 20. Ganho médio em peso $(\mathrm{kg})$ semanal das aves.

\begin{tabular}{|c|c|c|c|c|c|c|c|}
\hline \multirow[b]{2}{*}{ TRATAMENTO } & \multirow[b]{2}{*}{ BLOCO } & \multicolumn{6}{|c|}{ DIAS } \\
\hline & & 7 & 14 & 21 & 28 & 35 & 42 \\
\hline \multirow{7}{*}{ CONTROLE } & 1 & 0,086 & 0,244 & 0,389 & 0,529 & 0,500 & 0,595 \\
\hline & 2 & 0,092 & 0,255 & 0,373 & 0,495 & 0,582 & 0,608 \\
\hline & 3 & 0,086 & 0,238 & 0,385 & 0,487 & 0,578 & 0,521 \\
\hline & 4 & 0,077 & 0,268 & 0,395 & 0,500 & 0,497 & 0,651 \\
\hline & 5 & 0,092 & 0,250 & 0,395 & 0,507 & 0,579 & 0,618 \\
\hline & 6 & 0,098 & 0,270 & 0,398 & 0,495 & 0,575 & 0,598 \\
\hline & MÉDIA & 0,089 & 0,254 & 0,389 & 0,502 & 0,552 & 0,599 \\
\hline \multirow{7}{*}{$\begin{array}{l}\text { CITRATO } \\
\text { 1-21 DIAS }\end{array}$} & 1 & 0,089 & 0,255 & 0,390 & 0,510 & 0,597 & 0,558 \\
\hline & 2 & 0,094 & 0,253 & 0,385 & 0,480 & 0,590 & 0,534 \\
\hline & 3 & 0,096 & 0,258 & 0,400 & 0,507 & 0,610 & 0,529 \\
\hline & 4 & 0,097 & 0,260 & 0,395 & 0,513 & 0,570 & 0,545 \\
\hline & 5 & 0,095 & 0,270 & 0,400 & 0,512 & 0,603 & 0,560 \\
\hline & 6 & 0,103 & 0,270 & 0,390 & 0,495 & 0,595 & 0,590 \\
\hline & MÉDIA & 0,096 & 0,261 & 0,393 & 0,503 & 0,594 & 0,553 \\
\hline \multirow{7}{*}{$\begin{array}{l}\text { CITRATO } \\
22-42 \text { DIAS }\end{array}$} & 1 & 0,097 & 0,263 & 0,403 & 0,508 & 0,597 & 0,548 \\
\hline & 2 & 0,092 & 0,260 & 0,375 & 0,504 & 0,534 & 0,569 \\
\hline & 3 & 0,089 & 0,243 & 0,383 & 0,507 & 0,553 & 0,570 \\
\hline & 4 & 0,100 & 0,260 & 0,380 & 0,497 & 0,573 & 0,553 \\
\hline & 5 & 0,097 & 0,263 & 0,403 & 0,508 & 0,525 & 0,643 \\
\hline & 6 & 0,093 & 0,255 & 0,535 & 0,495 & 0,589 & 0,541 \\
\hline & MÉDIA & 0,095 & 0,257 & 0,413 & 0,503 & 0,562 & 0,571 \\
\hline \multirow{7}{*}{$\begin{array}{l}\text { CITRATO } \\
1-42 \text { DIAS }\end{array}$} & 1 & 0,091 & 0,255 & 0,378 & 0,514 & 0,621 & 0,533 \\
\hline & 2 & 0,081 & 0,243 & 0,379 & 0,539 & 0,564 & 0,538 \\
\hline & 3 & 0,092 & 0,243 & 0,400 & 0,517 & 0,605 & 0,578 \\
\hline & 4 & 0,096 & 0,255 & 0,393 & 0,510 & 0,607 & 0,578 \\
\hline & 5 & 0,087 & 0,238 & 0,365 & 0,497 & 0,608 & 0,553 \\
\hline & 6 & 0,091 & 0,240 & 0,373 & 0,527 & 0,605 & 0,579 \\
\hline & MÉDIA & 0,090 & 0,246 & 0,381 & 0,517 & 0,602 & 0,560 \\
\hline \multirow{7}{*}{ SULFATO } & 1 & 0,089 & 0,234 & 0,382 & 0,513 & 0,541 & 0,542 \\
\hline & 2 & 0,094 & 0,243 & 0,382 & 0,533 & 0,574 & 0,541 \\
\hline & 3 & 0,089 & 0,245 & 0,393 & 0,513 & 0,605 & 0,568 \\
\hline & 4 & 0,087 & 0,245 & 0,393 & 0,517 & 0,623 & 0,558 \\
\hline & 5 & 0,087 & 0,245 & 0,375 & 0,510 & 0,595 & 0,572 \\
\hline & 6 & 0,095 & 0,260 & 0,398 & 0,503 & 0,617 & 0,503 \\
\hline & MÉDIA & 0,090 & 0,245 & 0,387 & 0,515 & 0,593 & 0,547 \\
\hline
\end{tabular}


Apêndice 21. Consumo médio corrigido (kg) semanal das aves.

\begin{tabular}{|c|c|c|c|c|c|c|c|}
\hline \multirow[b]{2}{*}{ TRATAMENTO } & \multirow[b]{2}{*}{ BLOCO } & \multicolumn{6}{|c|}{ DIAS } \\
\hline & & 7 & 14 & 21 & 28 & 35 & 42 \\
\hline \multirow{7}{*}{ CONTROLE } & 1 & 0,173 & 0,373 & 0,611 & 0,870 & 1,054 & 1,345 \\
\hline & 2 & 0,168 & 0,401 & 0,595 & 0,851 & 1,100 & 1,324 \\
\hline & 3 & 0,180 & 0,410 & 0,578 & 0,853 & 1,095 & 1,070 \\
\hline & 4 & 0,188 & 0,371 & 0,579 & 0,859 & 1,054 & 1,362 \\
\hline & 5 & 0,175 & 0,401 & 0,590 & 0,865 & 1,108 & 1,341 \\
\hline & 6 & 0,180 & 0,398 & 0,608 & 0,893 & 1,133 & 1,343 \\
\hline & MÉDIA & 0,177 & 0,392 & 0,594 & 0,865 & 1,091 & 1,298 \\
\hline \multirow{6}{*}{$\begin{array}{l}\text { CITRATO } \\
1-21 \text { DIAS }\end{array}$} & 1 & 0,180 & 0,377 & 0,583 & 0,874 & 1,148 & 1,334 \\
\hline & 2 & 0,175 & 0,398 & 0,595 & 0,863 & 1,138 & 1,290 \\
\hline & 3 & 0,183 & 0,379 & 0,600 & 0,889 & 1,173 & 1,290 \\
\hline & 4 & 0,188 & 0,408 & 0,588 & 0,891 & 1,100 & 1,276 \\
\hline & 5 & 0,188 & 0,378 & 0,588 & 0,880 & 1,128 & 1,268 \\
\hline & 6 & 0,188 & 0,397 & 0,588 & 0,882 & 1,150 & 1,332 \\
\hline & MÉDIA & 0,184 & 0,390 & 0,590 & 0,890 & 1,140 & 1,298 \\
\hline \multirow{7}{*}{$\begin{array}{l}\text { CITRATO } \\
22-42 \text { DIAS }\end{array}$} & 1 & 0,175 & 0,355 & 0,593 & 0,890 & 1,163 & 1,287 \\
\hline & 2 & 0,173 & 0,406 & 0,578 & 0,868 & 1,079 & 1,299 \\
\hline & 3 & 0,183 & 0,352 & 0,570 & 0,859 & 1,100 & 1,309 \\
\hline & 4 & 0,195 & 0,406 & 0,580 & 0,879 & 1,103 & 1,309 \\
\hline & 5 & 0,183 & 0,355 & 0,590 & 0,868 & 1,080 & 1,360 \\
\hline & 6 & 0,180 & 0,347 & 0,590 & 0,878 & 1,138 & 1,288 \\
\hline & MÉDIA & 0,182 & 0,370 & 0,584 & 0,874 & 1,111 & 1,309 \\
\hline \multirow{7}{*}{$\begin{array}{l}\text { CITRATO } \\
1-42 \text { DIAS }\end{array}$} & 1 & 0,175 & 0,355 & 0,570 & 0,872 & 1,149 & 1,277 \\
\hline & 2 & 0,178 & 0,375 & 0,559 & 0,874 & 1,123 & 1,282 \\
\hline & 3 & 0,180 & 0,329 & 0,583 & 0,881 & 1,145 & 1,301 \\
\hline & 4 & 0,185 & 0,372 & 0,583 & 0,887 & 1,140 & 1,302 \\
\hline & 5 & 0,193 & 0,411 & 0,545 & 0,876 & 1,140 & 1,264 \\
\hline & 6 & 0,190 & 0,394 & 0,563 & 0,893 & 1,149 & 1,322 \\
\hline & MÉDIA & 0,187 & 0,373 & 0,567 & 0,881 & 1,141 & 1,291 \\
\hline \multirow{7}{*}{ SULFATO } & 1 & 0,188 & 0,396 & 0,564 & 0,859 & 1,077 & 1,240 \\
\hline & 2 & 0,185 & 0,406 & 0,562 & 0,877 & 1,097 & 1,257 \\
\hline & 3 & 0,188 & 0,358 & 0,575 & 0,875 & 1,138 & 1,258 \\
\hline & 4 & 0,183 & 0,347 & 0,568 & 0,879 & 1,143 & 1,292 \\
\hline & 5 & 0,190 & 0,430 & 0,558 & 0,873 & 1,100 & 1,300 \\
\hline & 6 & 0,190 & 0,362 & 0,585 & 0,895 & 1,165 & 1,197 \\
\hline & MÉDIA & 0,187 & 0,383 & 0,569 & 0,876 & 1,120 & 1,257 \\
\hline
\end{tabular}


Apêndice 22. Conversão alimentar média semanal das aves.

\begin{tabular}{|c|c|c|c|c|c|c|c|}
\hline \multirow[b]{2}{*}{ TRATAMENTO } & \multirow[b]{2}{*}{ BLOCO } & \multicolumn{6}{|c|}{ DIAS } \\
\hline & & 7 & 14 & 21 & 28 & 35 & 42 \\
\hline \multirow{7}{*}{ CONTROLE } & 1 & 2,01 & 1,53 & 1,57 & $\overline{1,64}$ & 2,11 & 2,26 \\
\hline & 2 & 1,82 & 1,57 & 1,60 & 1,72 & 1,89 & 2,18 \\
\hline & 3 & 2,09 & 1,73 & 1,50 & 1,75 & 1,90 & 2,05 \\
\hline & 4 & 2,44 & 1,39 & 1,47 & 1,72 & 2,12 & 2,09 \\
\hline & 5 & 1,90 & 1,61 & 1,49 & 1,71 & 1,91 & 2,17 \\
\hline & 6 & 1,84 & 1,47 & 1,53 & 1,80 & 1,97 & 2,25 \\
\hline & MÉDIA & 2,02 & 1,55 & 1,53 & 1,72 & 1,98 & 2,17 \\
\hline \multirow{7}{*}{$\begin{array}{l}\text { CITRATO } \\
\text { 1-21 DIAS }\end{array}$} & 1 & 2,02 & 1,48 & 1,49 & 1,72 & 1,92 & 2,39 \\
\hline & 2 & 1,86 & 1,58 & 1,55 & 1,80 & 1,93 & 2,41 \\
\hline & 3 & 1,90 & 1,47 & 1,50 & 1,75 & 1,92 & 2,44 \\
\hline & 4 & 1,94 & 1,57 & 1,49 & 1,74 & 1,93 & 2,34 \\
\hline & 5 & 1,98 & 1,40 & 1,47 & 1,72 & 1,87 & 2,26 \\
\hline & 6 & 1,82 & 1,47 & 1,51 & 1,78 & 1,93 & 2,26 \\
\hline & MÉDIA & 1,92 & 1,50 & 1,50 & 1,75 & 1,92 & 2,35 \\
\hline \multirow{7}{*}{$\begin{array}{l}\text { CITRATO } \\
\text { 22-42 DIAS }\end{array}$} & 1 & 1,80 & 1,35 & 1,47 & 1,75 & 1,95 & 2,35 \\
\hline & 2 & 1,88 & 1,56 & 1,54 & 1,72 & 2,02 & 2,28 \\
\hline & 3 & 2,06 & 1,45 & 1,49 & 1,69 & 1,99 & 2,30 \\
\hline & 4 & 1,96 & 1,56 & 1,53 & 1,77 & 1,93 & 2,37 \\
\hline & 5 & 1,88 & 1,35 & 1,47 & 1,71 & 2,06 & 2,12 \\
\hline & 6 & 1,94 & 1,36 & 1,10 & 1,77 & 1,93 & 2,38 \\
\hline & MÉDIA & 1,92 & 1,44 & 1,43 & 1,74 & 1,98 & 2,30 \\
\hline \multirow{7}{*}{$\begin{array}{l}\text { CITRATO } \\
1-42 \text { DIAS }\end{array}$} & 1 & 1,92 & 1,39 & 1,51 & 1,70 & 1,85 & 2,39 \\
\hline & 2 & 2,18 & 1,54 & 1,48 & 1,62 & 1,99 & 2,38 \\
\hline & 3 & 1,96 & 1,36 & 1,46 & 1,70 & 1,89 & 2,25 \\
\hline & 4 & 1,92 & 1,46 & 1,48 & 1,74 & 1,88 & 2,25 \\
\hline & 5 & 2,21 & 1,73 & 1,49 & 1,76 & 1,88 & 2,29 \\
\hline & 6 & 2,10 & 1,64 & 1,51 & 1,70 & 1,90 & 2,28 \\
\hline & MÉDIA & 2,05 & 1,52 & 1,49 & 1,70 & 1,90 & 2,31 \\
\hline \multirow{7}{*}{ SULFATO } & 1 & 2,11 & 1,69 & 1,48 & 1,68 & 1,99 & 2,29 \\
\hline & 2 & 1,97 & 1,67 & 1,47 & 1,65 & 1,91 & 2,32 \\
\hline & 3 & 2,11 & 1,46 & 1,46 & 1,71 & 1,88 & 2,22 \\
\hline & 4 & 2,10 & 1,41 & 1,45 & 1,70 & 1,84 & 2,32 \\
\hline & 5 & 2,20 & 1,76 & 1,49 & 1,71 & 1,85 & 2,27 \\
\hline & 6 & 1,99 & 1,39 & 1,47 & 1,78 & 1,89 & 2,38 \\
\hline & MÉDIA & 2,08 & 1,56 & 1,47 & 1,71 & 1,89 & 2,30 \\
\hline
\end{tabular}


Apêndice 23. Números de aves mortas semanal nas parcelas.

\begin{tabular}{|c|c|c|c|c|c|c|c|}
\hline \multirow[b]{2}{*}{ TRATAMENTO } & \multirow[b]{2}{*}{ BLOCO } & \multicolumn{6}{|c|}{ DIAS } \\
\hline & & 7 & 14 & 21 & 28 & 35 & 42 \\
\hline \multirow{7}{*}{ CONTROLE } & 1 & 0 & 1 & 1 & 1 & 0 & 0 \\
\hline & 2 & 0 & 0 & 0 & 0 & 0 & 0 \\
\hline & 3 & 0 & 0 & 0 & 0 & 0 & 1 \\
\hline & 4 & 0 & 0 & 1 & 0 & 0 & 0 \\
\hline & 5 & 0 & 0 & 0 & 2 & 0 & 0 \\
\hline & 6 & 0 & 0 & 0 & 0 & 0 & 0 \\
\hline & TOTAL & 0 & 1 & 2 & 3 & 0 & 1 \\
\hline \multirow{7}{*}{$\begin{array}{l}\text { CITRATO } \\
\text { 1-21 DIAS }\end{array}$} & 1 & 0 & 0 & 0 & 0 & 0 & 0 \\
\hline & 2 & 0 & 0 & 0 & 0 & 0 & 1 \\
\hline & 3 & 0 & 0 & 0 & 0 & 0 & 1 \\
\hline & 4 & 0 & 0 & 0 & 0 & 0 & 0 \\
\hline & 5 & 0 & 0 & 0 & 0 & 0 & 0 \\
\hline & 6 & 0 & 0 & 0 & 0 & 0 & 0 \\
\hline & TOTAL & 0 & 0 & 0 & 0 & 0 & 2 \\
\hline \multirow{7}{*}{$\begin{array}{l}\text { CITRATO } \\
22-42 \text { DIAS }\end{array}$} & 1 & 0 & 0 & 0 & 0 & 0 & 0 \\
\hline & 2 & 0 & 0 & 0 & 1 & 0 & 0 \\
\hline & 3 & 0 & 0 & 0 & 0 & 0 & 0 \\
\hline & 4 & 0 & 0 & 0 & 0 & 0 & 0 \\
\hline & 5 & 0 & 0 & 0 & 0 & 0 & 0 \\
\hline & 6 & 0 & 1 & 0 & 0 & 0 & 0 \\
\hline & TOTAL & 0 & 1 & 0 & 1 & 0 & 0 \\
\hline \multirow{7}{*}{$\begin{array}{l}\text { CITRATO } \\
1-42 \text { DIAS }\end{array}$} & 1 & $\overline{0}$ & $\overline{0}$ & $\overline{0}$ & $\overline{1}$ & 0 & 0 \\
\hline & 2 & 0 & 0 & 1 & 0 & 0 & 0 \\
\hline & 3 & 0 & 0 & 0 & 0 & 0 & 0 \\
\hline & 4 & 0 & 0 & 0 & 0 & 0 & 0 \\
\hline & 5 & 0 & 0 & 0 & 0 & 0 & 0 \\
\hline & 6 & 0 & 0 & 0 & 1 & 0 & 0 \\
\hline & TOTAL & 0 & 0 & 1 & 2 & 0 & 0 \\
\hline \multirow{7}{*}{ SULFATO } & 1 & 0 & 1 & 0 & 0 & 0 & 1 \\
\hline & 2 & 0 & 0 & 1 & 0 & 0 & 0 \\
\hline & 3 & 0 & 0 & 0 & 0 & 0 & 0 \\
\hline & 4 & 0 & 0 & 0 & 0 & 0 & 0 \\
\hline & 5 & 0 & 0 & 0 & 0 & 2 & 1 \\
\hline & 6 & 0 & 0 & 0 & 0 & 0 & 0 \\
\hline & TOTAL & 0 & 1 & 1 & 0 & 2 & 2 \\
\hline
\end{tabular}

